\title{
Particulate organic acids and overall water-soluble aerosol composition measurements from the 2006 Gulf of Mexico Atmospheric Composition and Climate Study (GoMACCS)
}

\author{
Armin Sorooshian, ${ }^{1}$ Nga L. Ng, ${ }^{1}$ Arthur W. H. Chan, ${ }^{1}$ Graham Feingold, ${ }^{2}$ \\ Richard C. Flagan, ${ }^{1}$ and John H. Seinfeld ${ }^{1}$ \\ Received 12 February 2007; revised 17 April 2007; accepted 26 April 2007; published 3 July 2007.
}

[1] The Center for Interdisciplinary Remotely-Piloted Aircraft Studies (CIRPAS) Twin Otter participated in the Gulf of Mexico Atmospheric Composition and Climate Study (GoMACCS) mission during August-September 2006. A particle-into-liquid sampler (PILS) coupled to ion chromatography was used to characterize the water-soluble ion composition of aerosol and cloud droplet residual particles (976 5-min $\mathrm{PM}_{1.0}$ samples in total). Sulfate and ammonium dominated the water-soluble mass $\left(\mathrm{NH}_{4}^{+}+\mathrm{SO}_{4}^{2-}=84 \pm\right.$ $14 \%$ ), while organic acids contributed $3.4 \pm 3.7 \%$. The average $\mathrm{NH}_{4}^{+}: \mathrm{SO}_{4}^{2-}$ molar ratio was $1.77 \pm 0.85$. Particulate concentrations of organic acids increased with decreasing carbon number from $\mathrm{C}_{9}$ to $\mathrm{C}_{2}$. Organic acids were most abundant above cloud, presumably as a result of aqueous phase chemistry in cloud droplets, followed by subsequent droplet evaporation above cloud tops; the main product of this chemistry was oxalic acid. The evolution of organic acids with increasing altitude in cloud provides evidence for the multistep nature of oxalic acid production; predictions from a cloud parcel model are consistent with the observed oxalate:glyoxylate ratio as a function of altitude in GoMACCS cumuli. Suppressed organic acid formation was observed in clouds with relatively acidic droplets, as determined by high particulate nitrate concentrations (presumably high $\mathrm{HNO}_{3}$ levels too) and lower liquid water content, as compared to other cloud fields probed. In the Houston Ship Channel region, an area with significant volatile organic compound emissions, oxalate, acetate, formate, benzoate, and pyruvate, in decreasing order, were the most abundant organic acids. Photo-oxidation of $m$-xylene in laboratory chamber experiments leads to a particulate organic acid product distribution consistent with the Ship Channel area observations.

Citation: Sorooshian, A., N. L. Ng, A. W. H. Chan, G. Feingold, R. C. Flagan, and J. H. Seinfeld (2007), Particulate organic acids and overall water-soluble aerosol composition measurements from the 2006 Gulf of Mexico Atmospheric Composition and Climate Study (GoMACCS), J. Geophys. Res., 112, D13201, doi:10.1029/2007JD008537.

\section{Introduction}

[2] Organic acids are ubiquitous in atmospheric aerosols [Kawamura and Ikushima, 1993; Stephanou and Stratigakis, 1993; Khwaja, 1995; Chebbi and Carlier, 1996; Kerminen et al., 2000; Yao et al., 2004]; however, their formation mechanisms are not entirely understood. Dicarboxylic acids have much lower vapor pressures (factor of 2 to 4 ) compared to monocarboxylic acids, which allows them to partition more easily into the aerosol phase [Ludwig and Klemm, 1988; Chebbi and Carlier, 1996]. Studies have shown that the particulate mass concentration of dicarboxylic acids tends to increase with decreasing carbon number

\footnotetext{
${ }^{1}$ Department of Chemical Engineering, California Institute of Technology, Pasadena, California, USA.

${ }^{2}$ Chemical Sciences Division, Earth System Research Laboratory, NOAA, Boulder, Colorado, USA.

Copyright 2007 by the American Geophysical Union. 0148-0227/07/2007JD008537
}

[Kawamura and Ikushima, 1993; Sempere and Kawamura, 1994; Kawamura et al., 1995; Kawamura and Sakaguchi, 1999; Limbeck and Puxbaum, 1999; Kerminen et al., 2000; Neususs et al., 2000]; consequently, oxalic acid $\left[(\mathrm{COOH})_{2}\right]$ is the dominant particulate dicarboxylic acid. Oxalic acid occurs both in primary emissions from fossil fuel combustion, biomass burning, and biogenic activity, as well as from photo-oxidation of volatile organic compounds (VOCs) and aqueous phase chemistry in cloud droplets [Norton et al., 1983; Kawamura and Kaplan, 1987; Kawamura and Ikushima, 1993; Faust, 1994; Chebbi and Carlier, 1996; Kerminen et al., 1999; Narukawa et al., 1999; Blando and Turpin, 2000; Yamasoe et al., 2000; Yao et al., 2002, 2003; Mochida et al., 2003; Turekian et al., 2003; Crahan et al., 2004; Yu et al., 2005; Sorooshian et al., 2006a]. (Huang and $Y u$ [2007] recently showed that vehicle exhaust is not a significant primary source for oxalate.) Sources of longerchain dicarboxylic acids $\left(\mathrm{C}_{9}\right.$ is the longest acid detected in the present study) include pyrolysis of vegetative material, 
vehicular emissions, photo-oxidation of aromatic hydrocarbons, and the oxidative decay of higher carbon number organic acids [Pereira et al., 1982; Rogge et al., 1991; Kawamura and Sakaguchi, 1999]. A major source of $\geq \mathrm{C}_{9}$ organic acids includes the oxidation of unsaturated $n$-fatty acids, which are emitted from microbial sources and the processing of plant and animal constituents [Rogge et al., 1993; Kawamura et al., 2005]; meat cooking is an especially significant source of fatty acid emissions [Rogge et $a l ., 1991]$. Lower carbon number dicarboxylic acids have been more frequently detected and at higher concentrations. The decrease in concentration of dicarboxylic acids with increasing carbon number, especially at higher altitudes, is suggestive of an oxidative decay mechanism; it is not certain, however, whether the lower carbon number acids are more abundant at lower altitudes simply as a result of larger primary emission rates.

[3] The monocarboxylic acids, of which formic and acetic acids are the most dominant in the gas phase, usually exhibit concentrations one to two orders of magnitude lower in the aerosol phase as compared to the gas phase [Chebbi and Carlier, 1996]. Formation mechanisms for these and other monocarboxylic acids include reactions of precursors in gas, aqueous, and particulate phases, and primary biogenic and anthropogenic emissions [Simoneit and Mazurek, 1982; Simoneit, 1986; Talbot et al., 1988; Rogge et al., 1991; Khwaja, 1995; Chebbi and Carlier, 1996; Souza et al., 1999; Kanakidou et al., 2005]. Although exceptions such as formic acid exist, monocarboxylic acids are generally thought to be oxidized to form dicarboxylic acids via intermediates such as hydroxyacids and ketocarboxylic acids [Kawamura and Ikushima, 1993].

[4] During August-September 2006, the Center for Interdisciplinary Remotely-Piloted Aircraft Studies (CIRPAS) Twin Otter (TO), based at Houston, Texas, participated in the Gulf of Mexico Atmospheric Composition and Climate Study (GoMACCS; http://www.esrl.noaa.gov/csd/2006/); 22 flights were devoted largely to probing aerosol-cloud relationships over the Gulf of Mexico and the inland Houston area. Previous field campaigns in southeastern Texas have addressed chemical characterization of aerosol in the Houston area (2000 Texas Air Quality Study (TexAQS; http://www.utexas.edu/research/ceer/texaqs); 2000_2001 Gulf Coast Aerosol Research and Characterization Study (GC-ARCH [Russell and Allen, 2004])); absent in those studies were rapid ( $\leq 5 \mathrm{~min}$ ) airborne measurements of speciated organic acids, in addition to inorganic species, in aerosol and cloud droplet residual particles. Table 1 provides a summary of reported urban organic aerosol measurements, with an emphasis on organic acids. These past measurements provide a body of urban data to which data from the Houston area during GoMACCS can be compared.

[5] The goal of the present work is twofold: (1) to provide a chemical characterization of inorganic and organic acid ions in southeastern Texas aerosol, including cloud droplet residual particles and (2) to gain insight into formation mechanisms for organic acids and their role in cloud droplet chemistry. Measurements of inorganic and organic acid species are first presented to gain insight into the spatial distribution of their mass concentrations, ionic charge balance closure, mass and volume concentration ratios in different air categories, and cross correlations between the different species. An in-depth analysis of each organic acid follows. The evolution of organic acids with increasing altitude in cloud is examined, and cloud parcel model predictions are compared to measurements to explain trends in the oxalate:glyoxylate ratio observed. Unique findings from cloud field measurements in high-nitrate areas are reported. Special attention is given to evidence of secondary organic aerosol (SOA) formed from aromatic VOCs, in which airborne data in the Houston Ship Channel area are compared to those from laboratory chamber photo-oxidation of $m$-xylene.

\section{Twin Otter (TO) Research Aircraft}

[6] The instrument payload on the TO aircraft is described elsewhere (http://www.cirpas.org). Two different inlets were employed for sampling clear air and clouds. A counterflow virtual impactor (CVI) inlet was used in cloud to isolate particles resulting from evaporation of cloud droplets (so-called residual particles). The main aircraft inlet sampled total aerosol outside of clouds and occasionally inside clouds, where the total aerosol consisted of interstitial aerosol and some evaporated droplet residual particles. Submicrometer aerosol chemical composition was measured by a particle-into-liquid sampler (PILS, Brechtel Manufacturing Inc.) [Sorooshian et al., 2006b]. In the PILS, submicrometer-sized ambient particles are grown into droplets sufficiently large to be collected by inertial impaction, allowing subsequent chemical analysis by ion chromatography (IC, Dionex). Samples are deposited in vials held on a rotating carousel, with each vial containing material representing a period of $5 \mathrm{~min}$ of flight, or alternatively, 62.5 L of sampled air (PILS sample flow rate = $12.5 \mathrm{~L} / \mathrm{min}$ ). IC analysis quantified the ambient air concentrations of water-soluble ions, including inorganic and organic acid ions.

[7] The detection limit (calculated as the average concentration plus three standard deviations of the smallest detectable peak for each ion in the IC baseline noise, converted to air-equivalent units) is $<0.1 \mu \mathrm{g} / \mathrm{m}^{3}$ for the inorganic ions $\mathrm{Na}^{+}, \mathrm{NH}_{4}^{+}, \mathrm{K}^{+}, \mathrm{Mg}^{2+}, \mathrm{Ca}^{2+}, \mathrm{Cl}^{-}, \mathrm{NO}_{2}^{-}$, $\mathrm{NO}_{3}^{-}$, and $\left.\mathrm{SO}_{4}^{2-}\right),<0.01 \mu \mathrm{g} / \mathrm{m}^{3}$ for the organic acid ions (saturated dicarboxylic acids $\mathrm{C}_{2}-\mathrm{C}_{9}$, acetic, formic, pyruvic, glyoxylic, maleic, malic, methacrylic, benzoic, and methanesulfonic acids), and $0.06 \mu \mathrm{g} / \mathrm{m}^{3}$ for the one amine measured, diethylamine. Since acetate, lactate, and glycolate coelute, these three are reported as a collective mass using the calibration equation of acetate; therefore the contribution of acetate reported is likely an overestimate. Compared to acetate, using the calibration equation of glycolate would yield values lower by $<10 \%$, with increasing peak area allowing for better agreement between the two calibration equations. A list of all organic acids studied with their respective structures and chemical formulas is given in Figure 1.

\section{Water-Soluble Chemical Characterization of Southeastern Texas Aerosol}

[8] The PILS collected 976 samples up to an altitude of $5 \mathrm{~km}$ over 22 flights during GoMACCS. Data were collected in the following regions of the atmosphere: free troposphere 


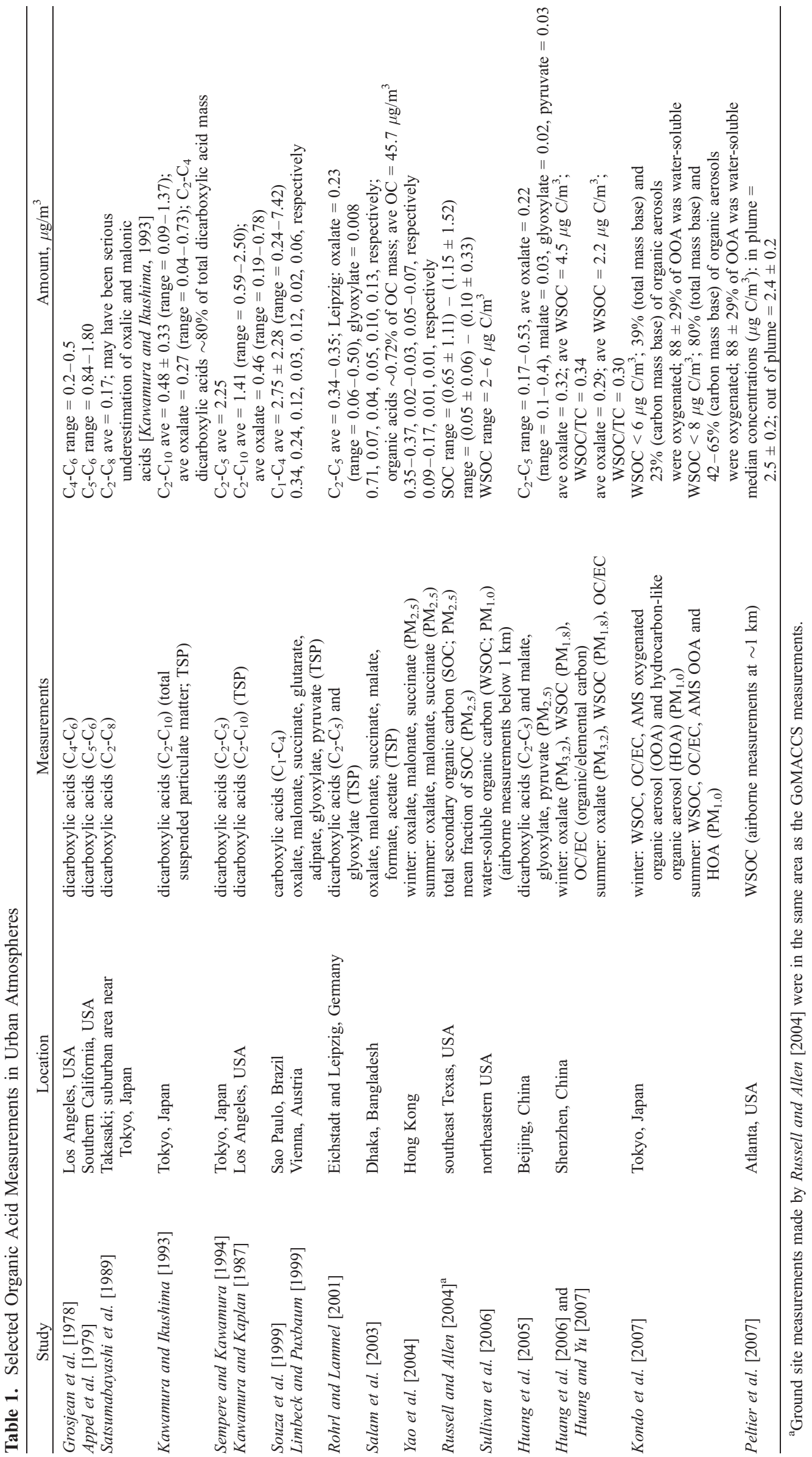




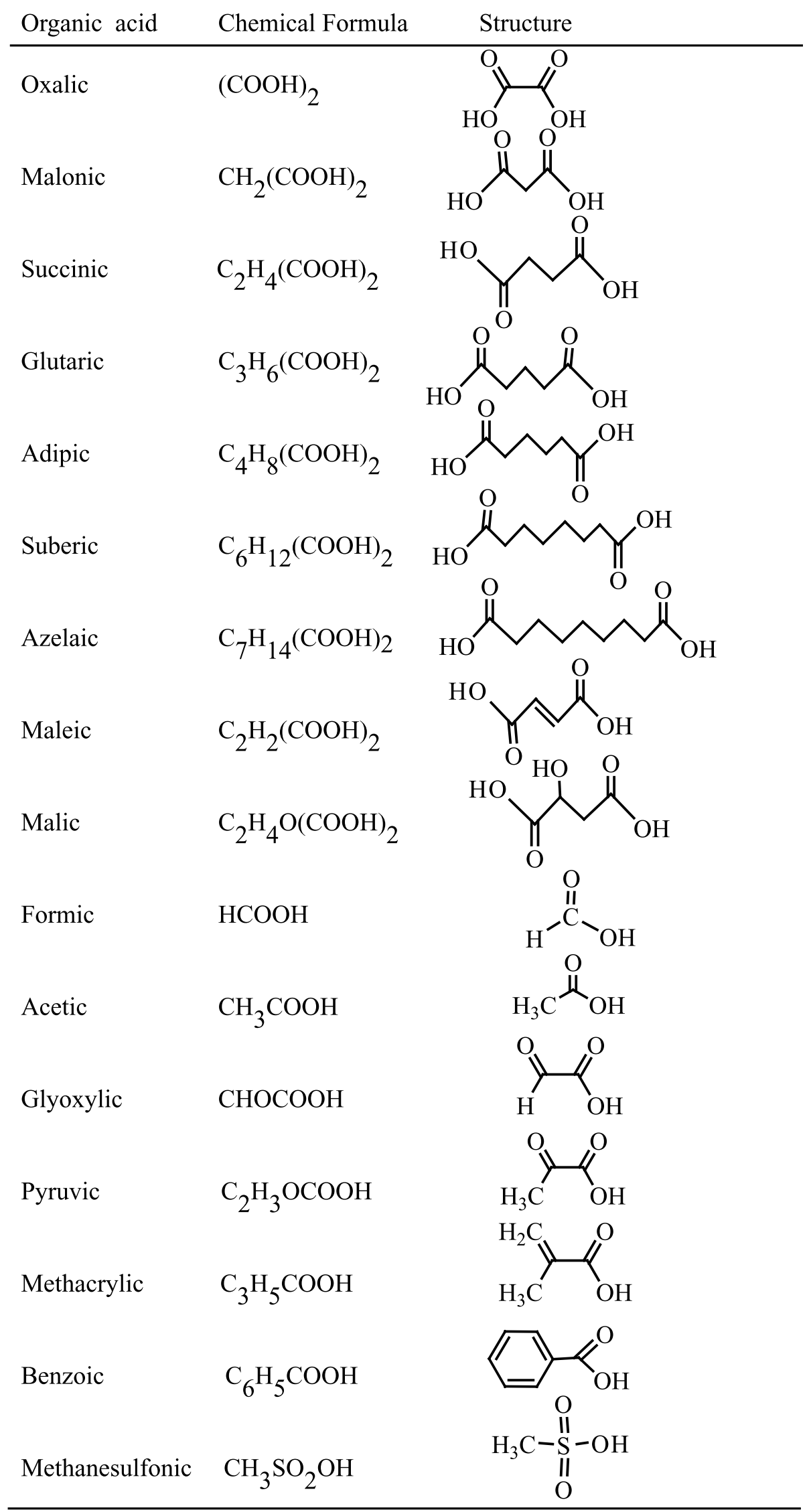

Figure 1. Chemical formulas and structures for the organic acids studied. 


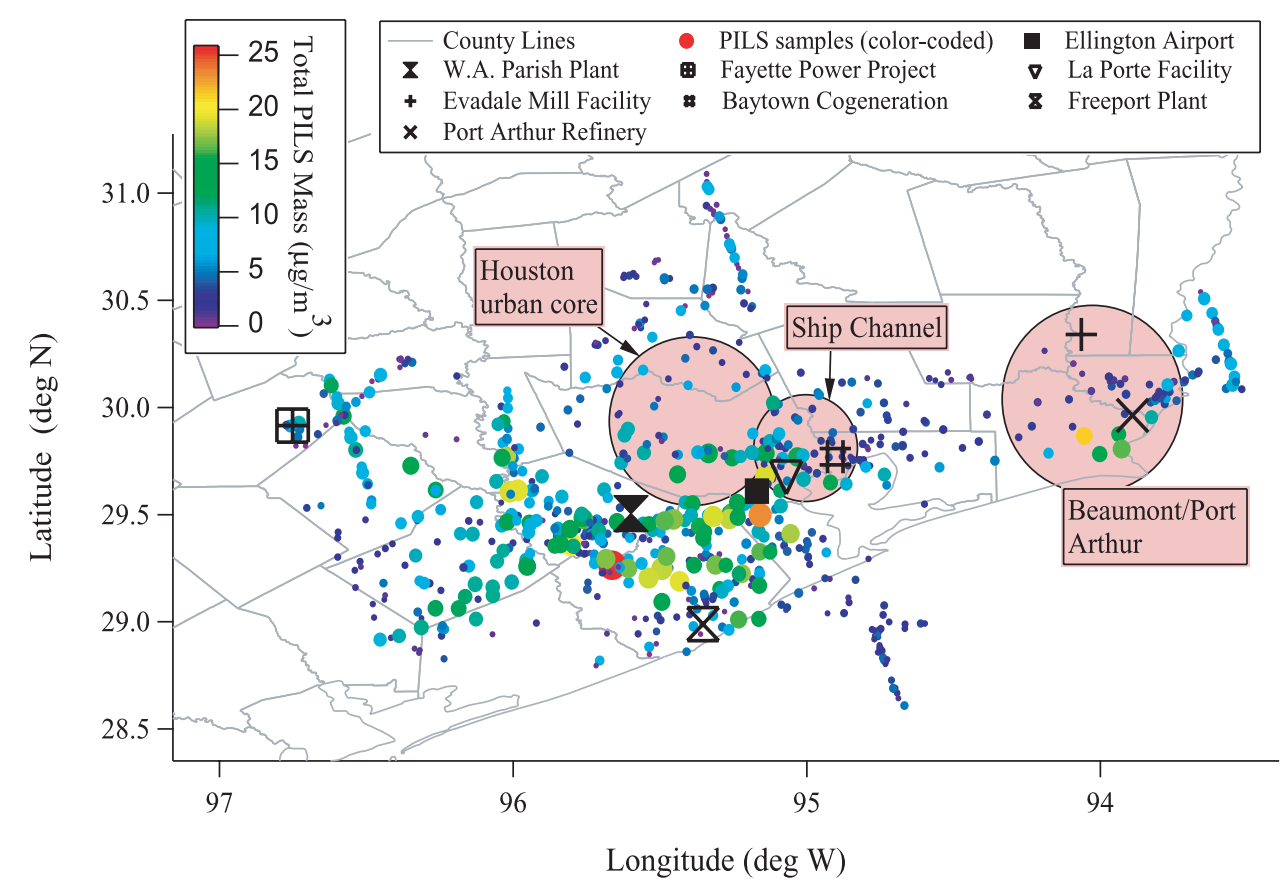

Figure 2. Spatial distribution of the PILS water-soluble mass concentration during GoMACCS. Marker sizes are proportional to sulfate concentration, where larger markers represent higher concentrations (range $=0.2-23.3 \mu \mathrm{g} / \mathrm{m}^{3}$ ).

(called "FT"; determined by meteorological sounding profiles), above cloud, inside cloud, below cloud, and in clear air in the boundary layer (BL) away from the vicinity of clouds (called "clear air").

[9] Figure 2 displays the spatial distribution of total water-soluble mass concentrations; the highest water-soluble mass concentrations (reported here with respective mass fraction of sulfate) in the BL occurred downwind of the W.A. Parish Power Plant $\left(8.9 \pm 3.7 \mu \mathrm{g} / \mathrm{m}^{3} ; \mathrm{SO}_{4}^{2-}=76 \pm\right.$ $6 \%)$, followed by the urban core of Houston $\left(7.7 \pm 3.4 \mu \mathrm{g} / \mathrm{m}^{3}\right.$; $\left.\mathrm{SO}_{4}^{2-}=69 \pm 10 \%\right)$, the Beaumont-Port Arthur area $(7.1 \pm$ $\left.4.5 \mu \mathrm{g} / \mathrm{m}^{3} ; \mathrm{SO}_{4}^{2-}=66 \pm 12 \%\right)$, the Houston Ship Channel $\left(6.3 \pm 3.9 \mu \mathrm{g} / \mathrm{m}^{3} ; \mathrm{SO}_{4}^{2-}=69 \pm 8 \%\right)$, and over the Gulf of Mexico $\left(2.9 \pm 1.4 \mu \mathrm{g} / \mathrm{m}^{3} ; \mathrm{SO}_{4}^{2-}=56 \pm 10 \%\right)$. The maximum mass concentration during the entire study $\left(25.74 \mu \mathrm{g} / \mathrm{m}^{3} ; \mathrm{SO}_{4}^{2-}=79 \%\right)$ was observed downwind of the Parish Plant.

[10] The overall water-soluble aerosol charge balance, as shown in Figure 3, has a slope of 0.80 indicating that there were unmeasured cations. The zero y-intercept indicates the absence of high background levels of anions and cations. Since sulfate and ammonium were the dominant species in aerosol sampled, the $\mathrm{NH}_{4}^{+}: \mathrm{SO}_{4}^{2-}$ molar ratio is a reliable indicator of the overall aerosol acidity in the region; Figure 3 shows that ratios $<2$ usually are associated with a negative charge balance. On average, the $\mathrm{NH}_{4}^{+}: \mathrm{SO}_{4}^{2-}$ molar ratio was $1.77 \pm 0.85$ during GoMACCS, indicating that ammonia $\left(\mathrm{NH}_{3}\right)$ was generally prevalent in the region. The vertical distribution of the charge balance shows that the most acidic aerosol occurred in clear air and at low altitudes close to $\mathrm{SO}_{2}$ sources; the $\mathrm{NH}_{4}^{+}: \mathrm{SO}_{4}^{2-}$ molar ratio was close to unity downwind of the Parish Plant.

[11] The PILS mass concentrations were reasonably correlated with DMA volume concentrations for aerosol in different vertical layers of the troposphere $\left(\mathrm{R}^{2}>0.5\right)$ with the exception of the FT $\left(\mathrm{R}^{2}=0.19\right)$ (Figure 4$)$. The highest correlation $\left(\mathrm{R}^{2}=0.64\right)$ was observed above cloud where the slope (aerosol density) was $1.46 \mathrm{~g} / \mathrm{cm}^{3}$ (density of pure ammonium sulfate $\left.=1.769 \mathrm{~g} / \mathrm{cm}^{3}\right)$. The slopes for other regions of the atmosphere in Figure 4 are less than unity. Many of the points exhibiting a higher volume concentration as compared to mass concentration (indicative of an aerosol density $<1 \mathrm{~g} / \mathrm{cm}^{3}$ ), especially in clear air, are downwind of major VOC sources. These samples may have contained organic species not detectable by the PILS-IC technique owing to insufficient water solubility and polarity. The FT data exhibited the lowest slope, suggesting that much of the mass was organic aerosol not quantifiable by the PILS-IC technique. The greatest mass fraction of organic acids occurred in above-cloud aerosol particles, as this layer has been shown to be enriched in water-soluble organic acids [Sorooshian et al., 2007]. A significant fraction of the organic acids above cloud may have been produced by in-cloud oxidation of less polar below-cloud species not able to be detected by the PILS-IC technique.

[12] The vertical mass distribution of the major inorganic species and total organic acids is shown in Figure 5. The total mass concentration usually peaked near $1 \mathrm{~km}$, and was lowest $\left(<5 \mu \mathrm{g} / \mathrm{m}^{3}\right)$ above $3 \mathrm{~km}$, an approximate altitude indicating the division between the BL and the FT. For all of the five air categories shown in Figure 5, the total mass was dominated by sulfate $(55-68 \%)$, followed by ammonium $(16-22 \%)$, and then nitrate $(5-12 \%)$. The mass fraction of organic acids increased with altitude from below cloud $(2 \%)$ to above cloud $(7 \%)$, while an intermediate mass fraction was observed in cloud droplet residual particles $(6 \%)$. The total organic acid mass did not decrease above cloud. Sulfate was highly correlated with ammonium $\left(\mathrm{R}^{2}=\right.$ 

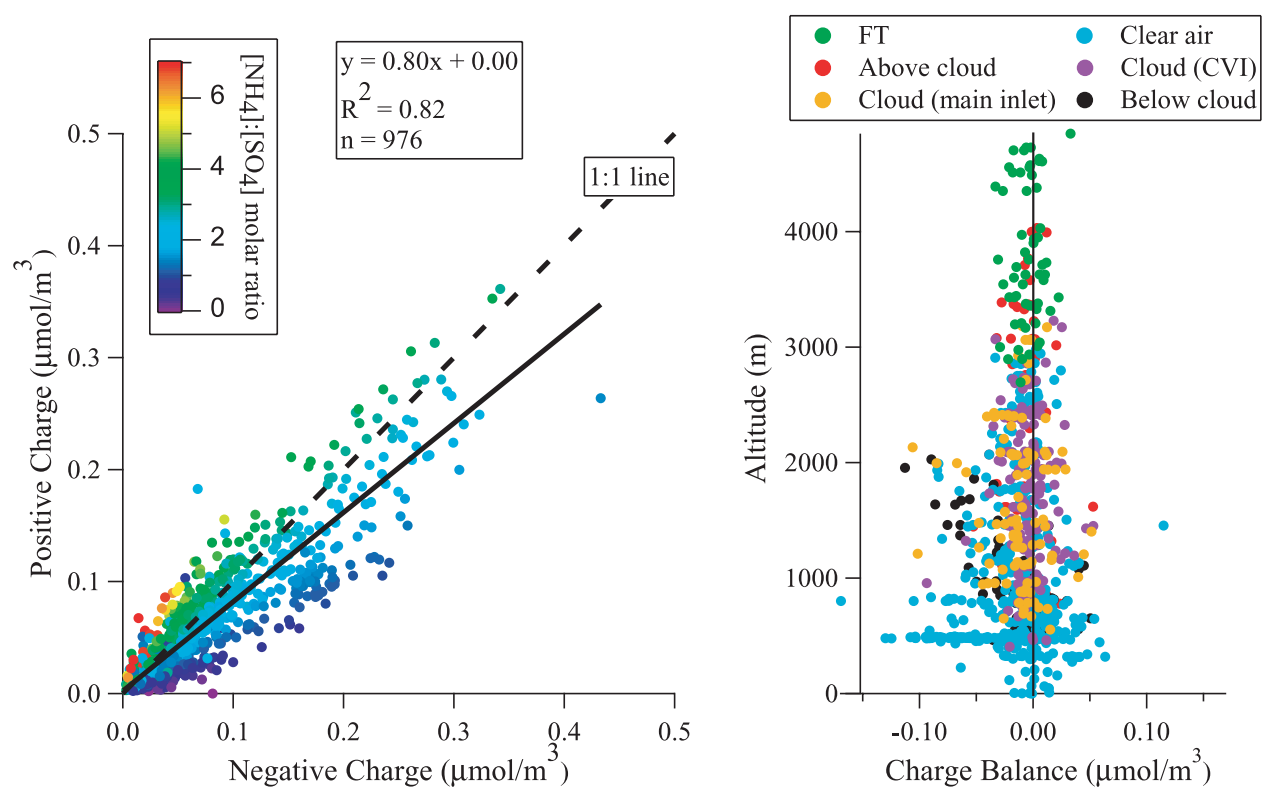

Figure 3. (left) Total water-soluble charge balance for all samples collected during GoMACCS. Markers are color coded with their respective $\mathrm{NH}_{4}^{+}: \mathrm{SO}_{4}^{2-}$ molar ratios. (right) Vertical distribution of the charge balance for samples categorized by the region of the lower troposphere they were collected in. Main inlet data in cloud refer to total aerosol samples, which contain interstitial aerosol and evaporated droplet residual particles. CVI data represent only evaporated droplet residual particles in cloud.

$0.84)$, followed by oxalate $\left(\mathrm{R}^{2}=0.33\right)$, which dominated the total organic acid mass. Cloud chemistry is likely the explanation for the observed correlation between sulfate and oxalic acid [Sorooshian et al., 2006a, 2007]. Although sulfate and oxalic acid are known to be produced by incloud oxidation of their gaseous precursors, sulfate typically decreased from below to above cloud while the sum of all organic acids, which was dominated by oxalic acid, exhibited the opposite behavior. This can be explained by the high background levels of sulfate at lower altitudes from local $\mathrm{SO}_{2}$ sources. Although there were local VOC sources as well, more lengthy chemistry, and consequently more time, is required to form oxalic acid from its parent gas phase precursors as compared to sulfate production from $\mathrm{SO}_{2}$.

[13] The mass fractions of the other inorganic species measured $\left(\mathrm{Na}^{+}, \mathrm{K}^{+}, \mathrm{Ca}^{2+}, \mathrm{Mg}^{2+}, \mathrm{Cl}^{-}, \mathrm{NO}_{2}^{-}, \mathrm{NO}_{3}^{-}\right)$were highest in the FT (cumulative $=13 \%$ ), presumably from long-range transport, and then above cloud (cumulative $=$ $3 \%)$. Sodium and chloride are best correlated with each other $\left(\mathrm{R}^{2}=0.45\right)$, likely owing to sea salt from the Gulf of Mexico. Nitrate shows poor correlation $\left(\mathrm{R}^{2}<0.1\right)$ with all other species except diethylamine $\left(\mathrm{R}^{2}=0.53\right)$, suggesting the presence of diethylamine nitrate in the atmosphere. Previous studies provide experimental and theoretical evidence for diethylamine nitrate being present in atmospheric aerosol [Angelino et al., 2001; Murphy et al., 2007]. Diethylamine reached levels as high as $0.08 \mu \mathrm{g} / \mathrm{m}^{3}(n=4$; Figure 6). When nitrite was measured $(n=4)$, it was best correlated with calcium $\left(\mathrm{R}^{2}=0.85\right)$; this suggests that nitrite was formed heterogeneously on the surface of calciumcontaining particles in these samples. The heterogeneous uptake and reactions of nitrogen oxides on the surface of calcium-containing particles have been well characterized [Grassian, 2001].
[14] Two flights over the Gulf of Mexico addressed cloud-processed and clear air aerosol. When comparing measurements at the same altitude range below $1100 \mathrm{~m}$ on these two days, the clear day was characterized by an

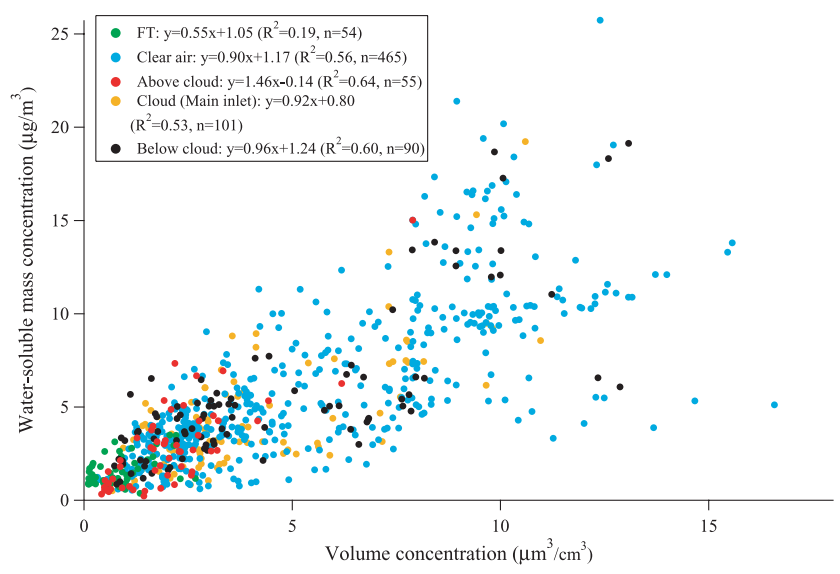

Figure 4. Comparison between the water-soluble mass concentration and DMA volume concentration in different regions of the lower troposphere. It should be noted that the size cutoff of the DMA was slightly less than the PILS (0.8 $\mu \mathrm{m}$ versus $1 \mu \mathrm{m})$, which may have led to an overestimate of the aerosol density, as represented by the slopes. The positive y-intercepts suggest that there may have been a systematic increase in the mass concentration as compared to what would be expected and this could also be due to the difference in the instrument size cutoff points. Forcing the intercepts of the regression lines to zero would compromise the relative nature of the individual data points. (The slopes in the case of a y-intercept of zero are as follows: $\mathrm{FT}=1.34$, clear air $=1.06$, above cloud $=1.41$, in cloud $($ total aerosol inlet $)=1.07$, and below cloud $=1.13$. 


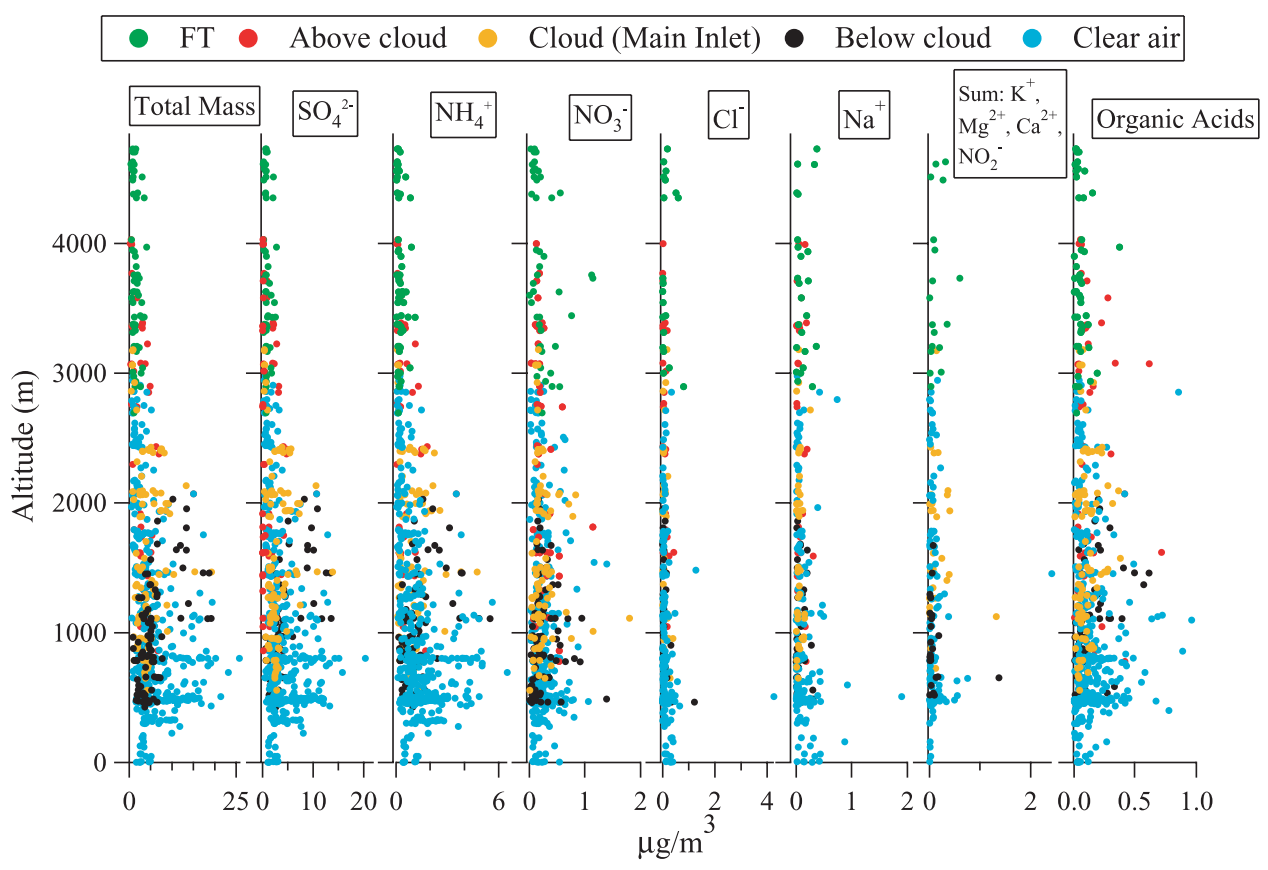

Figure 5. Vertical distribution of the total water-soluble mass and different ionic components. The data are categorized by what region of the lower troposphere the samples were collected in. Main inlet data in cloud refer to total aerosol samples, which contain interstitial aerosol and evaporated droplet residual particles.

average concentration of $0.05 \mu \mathrm{g} / \mathrm{m}^{3}$ and $0.02 \mu \mathrm{g} / \mathrm{m}^{3}$ for organic acids and oxalate, respectively, while the cloudy day yielded respective averages of $0.11 \mu \mathrm{g} / \mathrm{m}^{3}$ and $0.09 \mu \mathrm{g} / \mathrm{m}^{3}$. Cloud processing is hypothesized to have led to higher organic acid levels, especially oxalic acid, on the cloudy day. It is uncertain though the extent to which other conditions differed between the two days, such as VOC and oxidant levels. Methanesulfonate (MSA) was measured during these two Gulf flights, exhibiting its highest organic acid mass fractions below cloud (5\%) and in the FT (11\%), as compared to other data categories in Figure 7.

\section{Sources and Character of Organic Acids}

[15] As an average over 22 flights, the total concentration of the nine dicarboxylic acids measured $\left(\mathrm{C}_{2}-\mathrm{C}_{9}\right.$; includes saturated and unsaturated acids) was larger than those of seven monocarboxylic acids $\left(\mathrm{C}_{1}-\mathrm{C}_{7}\right.$; includes saturated and unsatu-

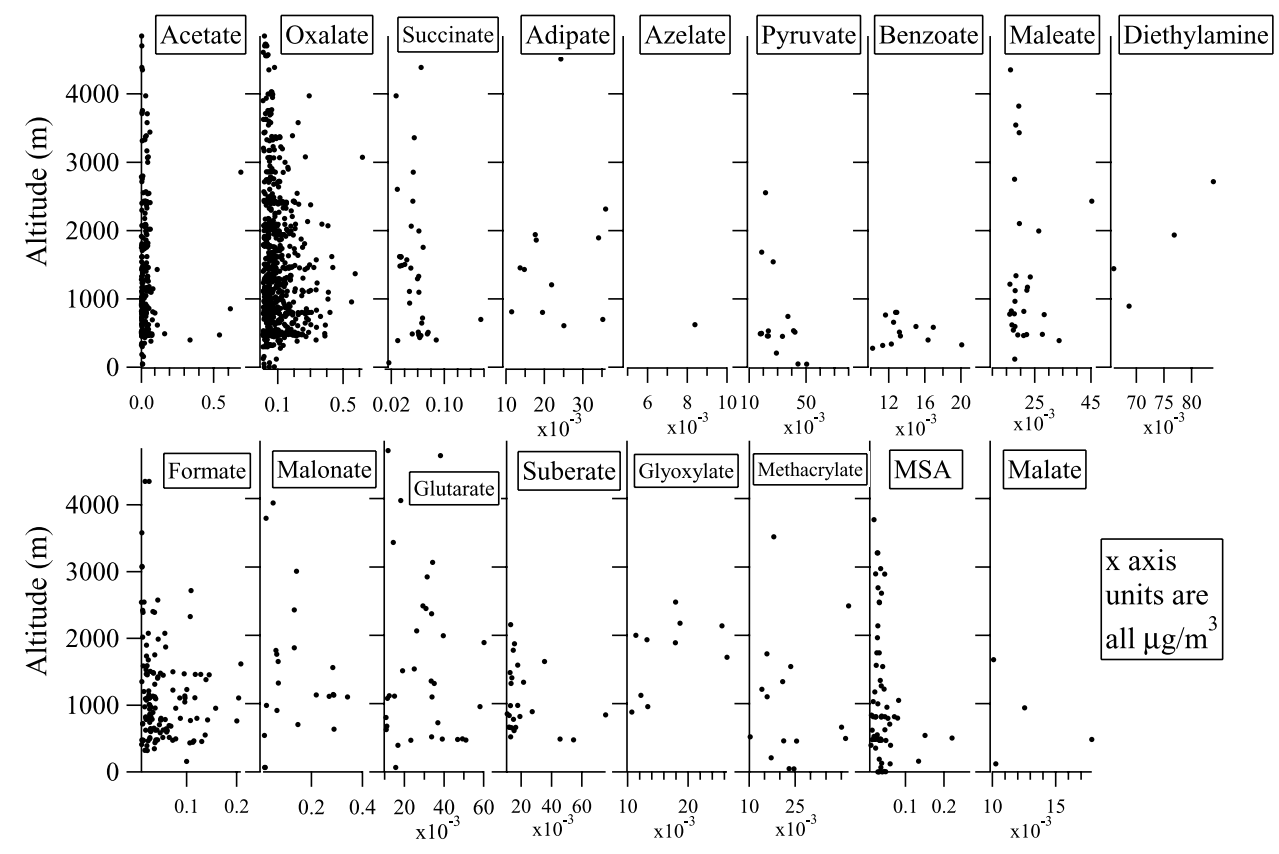

Figure 6. Vertical distribution of the different organic acids and diethylamine. 


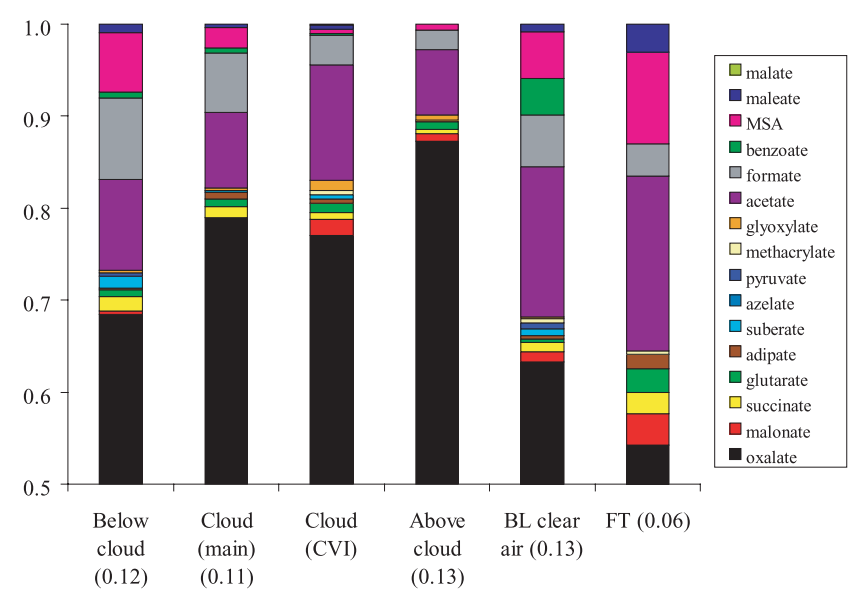

Figure 7. Contribution of individual organic acids to the total organic acid mass in different regions of the lower troposphere. To highlight less abundant organic acids, the y axis begins at $50 \%$ as oxalate contributes $>50 \%$ in each category. Average organic acid mass concentrations $\left(\mu \mathrm{g} / \mathrm{m}^{3}\right)$ for each category are shown in parentheses by each label on the $\mathrm{x}$ axis. Main inlet data in cloud refer to total aerosol samples, which contain interstitial aerosol and evaporated droplet residual particles. CVI data represent only evaporated droplet residual particles in cloud.

rated acids) $\left(0.09 \pm 0.10 \mu \mathrm{g} / \mathrm{m}^{3}\right.$ versus $\left.0.03 \pm 0.05 \mu \mathrm{g} / \mathrm{m}^{3}\right)$. Secondary organic carbon (SOC) measurements (difference between total OC and primary OC, averaged over two years) at urban sites in southeastern Texas during the 2000-2001 GC-ARCH study ranged from $0.65 \pm 1.11$ to $1.15 \pm 1.52 \mu \mathrm{g} \mathrm{C} / \mathrm{m}^{3}$ [(Table 1)] [Russell and Allen, 2004]; the total organic acids measured in GoMACCS account for an estimated $5-10 \%$ of the SOC reported in this prior study.

\subsection{Saturated Dicarboxylic Acids}

[16] Oxalate was the most abundant organic acid anion measured in GoMACCS. It exhibited higher organic acid mass fractions below $\left(0.08 \pm 0.10 \mu \mathrm{g} / \mathrm{m}^{3} ; 68 \%\right)$, inside $\left(0.09 \pm 0.07 \mu \mathrm{g} / \mathrm{m}^{3} ; 80 \%\right)$, and above clouds $\left(0.11 \pm 0.11 \mu \mathrm{g} / \mathrm{m}^{3} ; 85 \%\right)$, as compared to in clear air $\left(0.09 \pm 0.09 \mu \mathrm{g} / \mathrm{m}^{3} ; 64 \%\right)$ and the FT $\left(0.03 \pm 0.05 \mu \mathrm{g} / \mathrm{m}^{3}\right.$; $52 \%$ ) (Figures 6 and 7). These values tend to be less than those measured in other polluted urban atmospheres (as shown in Table 1, the measurements, the majority of which are from ground sites, are reported for different particle size ranges); oxalic acid exhibited a mean concentration of $1.14 \mu \mathrm{g} / \mathrm{m}^{3}$ in Sao Paulo, Brazil [Souza et al., 1999], $0.27 \mu \mathrm{g} / \mathrm{m}^{3}$ [Kawamura and Ikushima, 1993] and $1.35 \mu \mathrm{g} / \mathrm{m}^{3}$ [Sempere and Kawamura, 1994] in Tokyo, $0.22 \mu \mathrm{g} / \mathrm{m}^{3}$ in Beijing [Huang et al., 2005], $0.21 \mu \mathrm{g} / \mathrm{m}^{3}$ [Grosjean, 1988] and $0.06-0.36 \mu \mathrm{g} / \mathrm{m}^{3}$ (semiurban site $\left[\right.$ Khwaja, 1995]) in New York, $0.49 \mu \mathrm{g} / \mathrm{m}^{3}$ in Los Angeles [Kawamura et al., 1985], 0.35-0.37 $\mu \mathrm{g} / \mathrm{m}^{3}$ in Hong Kong during the winter $\left(0.09-0.17 \mu \mathrm{g} / \mathrm{m}^{3}\right.$ during summer) [Yao et al., 2004], $0.23 \mu \mathrm{g} / \mathrm{m}^{3}$ in Leipzig, Germany [Rohrl and Lammel, 2001], and $0.34 \mu \mathrm{g} / \mathrm{m}^{3}$ in Vienna, Austria [Limbeck and Puxbaum, 1999].

[17] In cloud droplets, oxalic acid is formed by oxidation of glyoxylic acid, the precursors of which include glyoxal, methylglyoxal, glycolic acid, pyruvic acid, and acetic acid
[Warneck, 2003; Ervens et al., 2004; Lim et al., 2005; Carlton et al., 2006]. Elevated organic acid layers above clouds, dominated by oxalic acid, can be explained, in part, by two likely mechanisms: evaporation of droplets near cloud tops, leaving residual particles that have newly formed oxalic acid, and entrainment from the FT above BL clouds [Sorooshian et al., 2007]. Oxalate is the most abundant organic acid in the FT, as it is a product of the oxidation of higher carbon number organic acids. For example, malonic acid is oxidized to form oxalic acid via intermediates such as hydroxymalonic acid or ketomalonic acid [Kawamura and Ikushima, 1993; Kawamura et al., 1996a; Kawamura and Sakaguchi, 1999]. Mainly because of the double bond, unsaturated dicarboxylic acids are oxidized to produce oxalic acid [Kawamura and Ikushima, 1993].

[18] The organic acid mass fractions of malonate $\left(\mathrm{C}_{3}\right)$, succinate $\left(\mathrm{C}_{4}\right)$, glutarate $\left(\mathrm{C}_{5}\right)$, and adipate $\left(\mathrm{C}_{6}\right)$ were greater in the FT $(3.4 \%, 2.2 \%, 2.7 \%$, and $1.6 \%$, respectively), as compared to below in the BL (Figure 7). Malonic acid is thought to be formed by oxidative decay of larger acids like succinic acid [Kawamura and Ikushima, 1993; Kawamura and Sakaguchi, 1999]. (Measurements, however, made in the Helsinki metropolitan area are not consistent with major malonic acid production from succinic acid [Kerminen et al., 2000].) A source of $\mathrm{C}_{4}-\mathrm{C}_{6}$ dicarboxylic acids is the ozonolysis of cyclic alkenes, such as cyclohexene, which are emitted by vehicles and have been reported to be present in urban atmospheres [Grosjean et al., 1978; Grosjean and Fung, 1984; Hatakeyama et al., 1985, 1987].

[19] Kawamura and Ikushima [1993] suggested that the $\mathrm{C}_{3}: \mathrm{C}_{4}$ ratio can be used as an indicator of enhanced photochemical production of dicarboxylic acids; they showed that malonate is less abundant than succinate in automobile exhaust, yet more abundant in Tokyo aerosol, presumably owing to secondary atmospheric production. In the present study, the $\mathrm{C}_{3}: \mathrm{C}_{4}$ ratio increased with increasing altitude up to $4 \mathrm{~km}$ (average $\mathrm{C}_{3}: \mathrm{C}_{4}$ up to $500 \mathrm{~m}=0.05$; $\mathrm{C}_{3}: \mathrm{C}_{4}>1$ from 500-4000 m), above which no malonate was detected. At a ground sampling site in Los Angeles in 1984 , an average $\mathrm{C}_{3}: \mathrm{C}_{4}$ ratio of 0.35 was reported for direct primary emissions from vehicular exhaust [Kawamura and Kaplan, 1987], while ratios $>1$ were reported for atmospheric aerosol in other studies [Kawamura and Ikushima, 1993; Kawamura et al., 1996b; Kawamura and Sakaguchi, 1999; Yao et al., 2002; Huang et al., 2005]; these values are consistent with the measurements in the present study. Because of oxidative decay, the $\mathrm{C}_{n}$ and $\mathrm{C}_{n+1}$ dicarboxylic acid pairs were usually well correlated [oxalate:malonate $\left(\mathrm{R}^{2}=0.72\right)$; succinate:glutarate $\left(\mathrm{R}^{2}=0.47\right)$; glutarate:adipate $\left.\left(\mathrm{R}^{2}=0.67\right)\right]$.

[20] The fraction of organic acid mass contributed by suberate peaked below cloud (1.3\%), with a clear air value of $0.7 \%$. Azelate was detected only in one clear air sample at $\sim 600 \mathrm{~m}\left(\sim 0.01 \mu \mathrm{g} / \mathrm{m}^{3}\right)$. Azelaic acid is known to be an oxidation product from biogenic unsaturated fatty acids, mainly those containing a double bond at the C-9 position [Yokouchi and Ambe, 1986; Kawamura and Gagosian, 1987; Kawamura and Kaplan, 1987; Narukawa et al., 1999]. $C_{8}$ and $C_{9}$ dicarboxylic acids decreased in concentration rapidly with increasing altitude, presumably because 
the aged aerosol has undergone oxidative decay of these and other longer-chain acids.

\subsection{Unsaturated and Hydroxylated Dicarboxylic Acids}

[21] Photo-oxidation of aromatic hydrocarbons is known to lead to ring-cleavage reactions and produce $\mathrm{C}_{2}-\mathrm{C}_{5}$ dicarbonyls that are subsequently oxidized to form dicarboxylic acids [Kawamura and Ikushima, 1993; Calvert et al., 2002]. Maleic acid, an unsaturated dicarboxylic acid, is produced by photo-oxidation of benzene [Kawamura and Ikushima, 1993; Kawamura et al., 1996a] and is emitted from diesel and gasoline engines [Rogge et al., 1993]. The organic acid mass fraction of maleate was highest in the FT $(3.2 \%)$ (Figure 7$)$. It was correlated most closely with benzoate $\left(\mathrm{R}^{2}=1, n=3\right)$, followed by glutarate $\left(\mathrm{R}^{2}=\right.$ $0.52)$, formate $\left(\mathrm{R}^{2}=0.39\right)$, succinate $\left(\mathrm{R}^{2}=0.16\right)$, and acetate $\left(\mathrm{R}^{2}=0.15\right)$. Maleic and succinic acids exhibit similar vertical distributions; the most direct link between these two species is formation of succinic acid by hydrogenation of maleic acid, although there is no clear evidence from the present data to support this mechanism. Benzoic acid, like maleic acid, is also produced by the oxidation of aromatic hydrocarbons, specifically toluene [Forstner et al., 1997; Jang and Kamens, 2001]. Maleic acid is expected to be further oxidized to produce malonic and oxalic acids, or transformed to fumaric acid, an isomer of maleic acid [Kawamura et al., 2005]. Kawamura and Ikushima [1993] reported that the cis-configuration (maleic acid) is generally more abundant than the trans-configuration (fumaric acid).

[22] Malic acid, whose anion (malate) was detected in only four samples, is a hydroxylated dicarboxylic acid that can be formed by hydration of maleic acid and hydroxylation of succinic acid [Kawamura and Ikushima, 1993; Kawamura and Sakaguchi, 1999; Kawamura et al., 2005]. Evidence for the hydroxylation reaction is based on detection of $\mathrm{C}_{5}$ and $\mathrm{C}_{6}$ hydroxyacids [Appel et al., 1979]. It has been proposed that the oxidation of succinic acid can form malonic acid with malic acid acting as an intermediate [Kawamura and Ikushima, 1993]. Succinate was not measured in the same samples as malic acid, but it was twice measured in samples collected immediately after a sample containing malate. Malate and maleate were measured together in one sample. Malate was best correlated with acetate $\left(\mathrm{R}^{2}=0.89\right)$ and oxalate $\left(\mathrm{R}^{2}=0.77\right)$; oxalic and malonic acids are known oxidation products of malic acid [Kawamura and Ikushima, 1993], but it is uncertain as to whether acetic acid is also an oxidative product. Malate exhibited low concentrations (maximum of $0.02 \mu \mathrm{g} / \mathrm{m}^{3}$ ) and was detected only below $2 \mathrm{~km}$.

\subsection{Saturated Monocarboxylic Acids}

[23] After oxalate, the next most abundant particulate organic acid measured in GoMACCS was acetate, with formate and several other acids with similar concentrations following. Acetate was measured more frequently than formate; acetic acid has a higher Henry's Law coefficient and a lower vapor pressure as compared to formic acid, which allows it to partition more easily into the aerosol phase [Saxena and Hildemann, 1996]. The organic acid mass fraction of acetate peaked in the FT $(20 \pm 28 \%)$ (Figure 7). Acetate and formate were the most abundant organic acids in droplet residual particles after oxalate, contributing $13 \%$ and $3 \%$ to the total organic acid mass, respectively. This suggests that acetate and formate are active components in droplet chemistry; acetic acid is further oxidized in the aqueous phase to yield oxalic (with glyoxylic acid as an intermediate) and formic acids [Lim et al., 2005; Carlton et al., 2006]. Some of the highest acetate concentrations (maximum of $0.6 \mu \mathrm{g} / \mathrm{m}^{3}$ ) occurred in the Houston Ship Channel area. As will be discussed later, the oxidation of aromatic VOCs leads preferentially to acetate and formate, as compared to other organic acids studied.

[24] Pyruvic acid, the main oxidation product of methylglyoxal, has been shown to originate from biogenic sources such as isoprene [Talbot et al., 1995]; it is also a precursor to oxalic acid in the aqueous phase [Lim et al., 2005; Carlton et al., 2006]. Pyruvate was detected only in clear air and below cloud, suggesting that it is rapidly oxidized in the condensed phase to form products of higher polarity such as acetic and oxalic acids [Lim et al., 2005; Carlton et al., 2006]. Pyruvate has been reported in other urban areas (Table 1); pyruvic acid concentrations ranged between 0.06 and $1.15 \mu \mathrm{g} / \mathrm{m}^{3}$ in Sao Paulo [Souza et al., 1999], between 0.04 and $0.10 \mu \mathrm{g} / \mathrm{m}^{3}$ in Schenectady, New York [Khwaja, 1995], and exhibited an average of $0.03 \mu \mathrm{g} / \mathrm{m}^{3}$ in Beijing [Huang et al., 2005] and $0.06 \mu \mathrm{g} / \mathrm{m}^{3}$ in Vienna [Limbeck and Puxbaum, 1999]. In the present study, pyruvate is most closely correlated with benzoate $\left(\mathrm{R}^{2}=0.42\right)$ and methacrylate $\left(\mathrm{R}^{2}=0.26\right)$. Souza et al. [1999] showed that oxalic and pyruvic acids were well correlated $\left(\mathrm{R}^{2}=0.67\right)$ in Sao Paulo. As will be discussed, pyruvate is a product in the photooxidation of aromatic VOCs, similar to benzoate, acetate, and oxalate.

[25] The fraction of organic acid mass contributed by glyoxylate was a maximum in droplet residual samples (1.1\%), because it is likely an immediate precursor to oxalic acid in the aqueous phase [Sorooshian et al., 2006a]. As evidenced by its vertical distribution, glyoxylate was usually detected at altitudes corresponding to those where clouds were present. Glyoxylic acid is produced by the oxidation of glyoxal and glycolic acid [Kawamura et al., 1996a; Ervens et al., 2004]. Glyoxylate exhibited its strongest correlation with formate $\left(\mathrm{R}^{2}=0.91\right)$, followed by benzoate $\left(\mathrm{R}^{2}=0.58\right)$. As will be discussed, glyoxylate is an oxidative product, similar to formic and benzoic acids, from the photo-oxidation of aromatic VOCs.

\subsection{Unsaturated Monocarboxylic Acids}

[26] Methacrylic acid is a second-generation gas phase oxidation product of isoprene, formed from methacrolein $\left(\mathrm{C}_{4} \mathrm{H}_{6} \mathrm{O}\right)$ oxidation [Claeys et al., 2004]. The methacrolein Henry's Law constant, $6.5 \mathrm{M} / \mathrm{atm}$, is too low for it to participate directly in SOA formation [Iraci et al., 1999; Gelencser and Varga, 2005]. Methacrylic acid has a Henry's Law constant of $2 \times 10^{3} \mathrm{M} / \mathrm{atm}$; this value is such that it is a possible precursor for other organic acids in the aqueous phase [Meylan and Howard, 1991; Gelencser and Varga, 2005]. (Assuming a pH range of 2-5 for cloud droplets, the effective Henry's Law constant, $K_{\mathrm{H} \text {,eff }}=K_{\mathrm{H}} *\left(1+K_{\mathrm{a}} /\right.$ $\left.\left[\mathrm{H}^{+}\right]\right)$, is calculated to be between $2 \times 10^{3} \mathrm{M} / \mathrm{atm}$ and $6.4 \times$ $10^{3} \mathrm{M} / \mathrm{atm}$.) An IC peak corresponding to that at which methacrylate normally elutes was detected in both clear air and cloud droplet residual samples. Tests were done to see if another anion, 2-methylglycerate, elutes at the same time as 


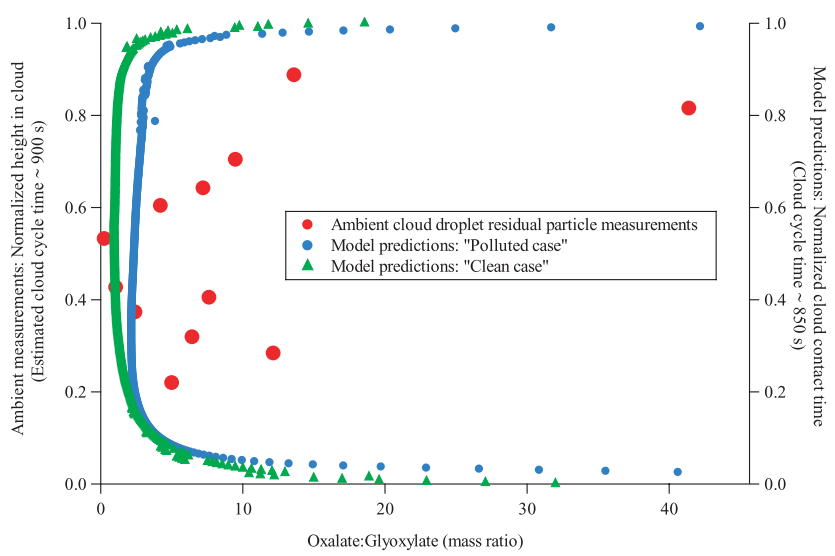

Figure 8. Comparison of the oxalate:glyoxylate mass ratio between ambient measurements of cloud droplet residual particles and model predictions for clouds influenced by pollution sources ("polluted") and those that are not ("clean"). The chemical cloud parcel model considers mean cloud-contact times on the order of $\sim 850 \mathrm{~s}$, while the estimated value for the ambient case, using average cloud depth and updraft velocity, is $\sim 900 \mathrm{~s}$.

methacrylate; methacrylic acid is thought to form 2-methylglyceric acid $\left(\mathrm{C}_{3} \mathrm{H}_{7} \mathrm{O}_{2} \mathrm{COOH}\right.$; also called 2,3-dihydroxy2-methylpropanoic acid) via oxidation [Claeys et al., 2004]. After synthesizing standards for 2-methylglyceric acid and analyzing them by IC, no conclusive evidence was found that 2-methylglycerate coelutes with methacrylate. In addition, field samples were too dilute to give any signal by LC/ ESI-MS (liquid chromatography/electrospray ionizationmass spectrometry) in the negative ion mode for methacrylic and 2-methylglyceric acids. It is also unclear as to whether methacrylic acid was formed in the droplet growth chamber of the PILS as a decomposition product of larger species such as polymers. This species, measured to be $<0.04 \mu \mathrm{g} / \mathrm{m}^{3}$, will be termed methacrylate henceforth; it was best correlated with pyruvate $\left(\mathrm{R}^{2}=0.26\right)$ and glyoxylate $\left(\mathrm{R}^{2}=0.15\right)$, two other species active in the aqueous phase chemistry of isoprene oxidation products [Lim et al., 2005; Carlton et al., 2006]. Methacrylate will be discussed in more detail subsequently.

[27] Benzoate was measured most frequently in clear air and in the vicinity of the Houston Ship Channel and urban core area. Benzoate was detected only below $1 \mathrm{~km}$, suggesting that it is likely oxidized rapidly. Aromatic hydrocarbons are emitted by numerous point sources in the Houston area, with a high density of sources in the Ship Channel area (http://www.esrl.noaa.gov/csd/2006/fieldops/emission.html). Toluene constitutes one of these species emitted, and its gas phase oxidation leads to benzoic acid as a product [Forstner et al., 1997; Jang and Kamens, 2001; Hamilton et al., 2005]. Jang and Kamens [2001] showed that in the presence of $\mathrm{NO}_{\mathrm{x}}$ and 1-propene, 7-12\% of the toluene-OH radical reaction yields benzaldehyde after $\mathrm{H}$-abstraction from the methyl group. On the basis of data from five different studies, Calvert et al. [2002] suggested an average yield of $6 \pm 1 \%$ for the same reaction pathway. After subsequent oxidation of benzaldehyde, benzoic acid is produced from the benzoylperoxy radical- $\mathrm{HO}_{2}$ reaction. It should be noted, however, that Kleindienst et al. [2004] did not detect particulate benzoic acid in toluene photo-oxidations and attributed its detection in the previous studies of Forstner et al. [1997] and Jang and Kamens [2001] to be a result of high initial concentrations of aromatic and $\mathrm{NO}_{\mathrm{x}}$ gases, which lead to significant levels of ring-retaining products. When detected during GoMACCS, benzoate was well correlated with glutarate and succinate $\left(\mathrm{R}^{2}=0.98\right.$ and 0.63 , respectively), which represent ring-opening products from the oxidation of $\mathrm{C}_{5}-\mathrm{C}_{7}$ cycloalkenes [Hatakeyama et al., 1985; Kalberer et al., 2000]. Benzoate was highly correlated with maleate $\left(\mathrm{R}^{2}=1, n=3\right)$, glyoxylate $\left(\mathrm{R}^{2}=\right.$ $0.58)$, and pyruvate $\left(R^{2}=0.42\right)$, all of which will be shown later to be products from the photo-oxidation of aromatic VOCs.

\section{Role of Organic Acids in Cloud Droplet Chemistry}

\subsection{Oxalic Acid as a Reaction Product in Clouds}

[28] The below-cloud organic acid product distribution was dominated by oxalate $(69 \%)$, followed by acetate $(10 \%)$, formate $(9 \%)$, and MSA (6\%) (Figure 7). In cloud droplet residual particles, the distribution of organic acids changed as a result of cloud phase reactions forming oxalic acid through its main intermediate, glyoxylic acid [Sorooshian et al., 2006a, 2007]. Glyoxylate, which contributed an average of $0.2 \%$ to the organic acid mass below cloud, accounted for $1.1 \%$ in droplet residual particles. Oxalic acid can also be produced by malonic acid oxidation [Ervens et al., 2004; Sorooshian et al., 2006a], and malonate contributed $1.7 \%$ to the organic acid mass in droplet residual particles, as compared to a $0.3 \%$ contribution to below-cloud aerosol. The source of malonic acid was most likely the decarboxylation of larger dicarboxylic acids such as succinic acid [Ervens et al., 2004]. Acetic acid is an aqueous phase precursor to glyoxylic acid [Lim et al., 2005; Carlton et al., 2006], and it contributed $12.6 \%$ to the organic acid mass in droplet residual particles as opposed to $9.9 \%$ in below-cloud aerosol. The oxalate contribution to the organic acid mass increased to $77 \%$ in cloud droplet residual particles as a result of aqueous phase reactions [Ervens et al., 2004; Sorooshian et al., 2006a]. As the droplets above cloud evaporated, the organic acid product distribution was shifted even more toward oxalic acid, as it contributed $87 \%$ to the organic acid mass, while acetate, glyoxylate, and malonate decreased to $7 \%, 1 \%$, and $0.7 \%$, respectively.

[29] Droplet residual particle composition was studied as a function of altitude in cloud. With increasing altitude in cloud, the cumulative average of the oxalate:glyoxylate ratio in all clouds studied decreased and then increased (just above base $=78$; midlevel $=19$; just below top $=232$ ); this behavior suggests that glyoxylic acid is produced most rapidly in the bottom half of clouds, while oxalic acid is produced most efficiently in the top half of the clouds by glyoxylic acid oxidation. An average is reported here since glyoxylate did not achieve sufficiently high concentrations at multiple heights in more than a couple individual cloud fields. In-cloud data from all samples containing both oxalate and glyoxylate from different flights are shown together in Figure 8 as a function of normalized height in cloud (height above cloud base/cloud thickness). The oxalate:glyoxylate ratio decreases from the lower portions of 
clouds to the midpoint, at which point the ratio increases with increasing altitude.

[30] Ambient measurements of the oxalate:glyoxylate ratio are compared to predictions of a state-of-the-art microphysical/chemical cloud parcel model [Ervens et al., 2004] that simulates the activation of a population of aerosol particles. The model simulates cloud cycles that are intended to represent the trajectory of a typical air parcel in a cloudy atmosphere, including gas and aqueous phase chemical reactions. The parcel follows a prescribed trajectory that encounters a cloud for a fixed period of time ( $\sim 850 \mathrm{~s}$ each cycle). During a cloud cycle, a parcel ascends from the base of a cloud to its top and then descends back down. Four gas phase VOC precursors of dicarboxylic acids are included in the model chemistry; toluene and ethene represent anthropogenic emissions, isoprene represents biogenic emissions, and cyclohexene serves as a model compound for symmetrical alkenes similar to monoterpenes emitted by biogenic sources. Oxidation products of these species in the gas phase (glyoxal, glyoxylic acid, glycolic acid, hydroxyacetaldehyde, methylglyoxal, pyruvic acid, acetic acid, adipic acid, and glutaric acid) can transfer to the aqueous phase to undergo reactions to form lowervolatility products. The same initial conditions used by Sorooshian et al. [2006a] are used to simulate two conditions: clouds uninfluenced by local pollution sources ("clean" initial concentrations: 1755 particles $/ \mathrm{cm}^{3}, 0.5 \mathrm{ppb}$ $\mathrm{SO}_{2}, 40 \mathrm{ppb} \mathrm{O}_{3}, 1 \mathrm{ppb} \mathrm{H}_{2} \mathrm{O}_{2}, 0.04-0.06 \mathrm{ppb}$ each for isoprene, toluene, cyclohexene, ethene) and clouds immediately impacted by pollution sources ("polluted" initial concentrations: 4890 particles $/ \mathrm{cm}^{3}, 69.5 \mathrm{ppb} \mathrm{SO}_{2}, 40 \mathrm{ppb}$ $\mathrm{O}_{3}, 1 \mathrm{ppb} \mathrm{H}_{2} \mathrm{O}_{2}, 0.04-0.11 \mathrm{ppb}$ each for isoprene, toluene, cyclohexene, ethene).

[31] In order to evaluate the comparison between the predicted and observed oxalate:glyoxylate ratio, it is necessary to compare cloud-contact times in the model and in the Houston cumulus clouds studied. Ervens et al. [2004] used trajectories derived from modeling of stratocumulus clouds and showed mean contact times with cloud on the order of $\sim 850 \mathrm{~s}$ (14 min). For the current study we use model trajectories for shallow cumulus clouds based on model simulations of GoMACCS cases as well as simple calculations based on updraft velocities and cloud depth. The stratocumulus clouds in the previous work were shallower $(<200 \mathrm{~m})$ as compared to GoMACCS clouds (average depth $\sim 1100 \mathrm{~m}$ ), but the more convective clouds in GoMACCS exhibited higher updraft velocities $(1.2 \pm 1.3 \mathrm{~m} / \mathrm{s})$. Using the average GoMACCS cloud depth and updraft velocity measured, an estimate of the cloud-contact time for one cloud cycle is $\sim 900 \mathrm{~s}(15 \mathrm{~min})$. There are obvious uncertainties in this estimate such as the assumption of no variability in cloud depth or updraft velocity during the time the aircraft was probing a single cloud field. Model simulations of air parcel trajectories in cumulus clouds in the Houston area show that among 500 parcels initialized in the BL, approximately $30 \%$ spent more than 6 min in cloud, and some parcels spent up to $21 \mathrm{~min}$ in cloud. Since the oxalate:glyoxylate data are reported from some of the largest clouds studied, it is likely that many of the parcels were in contact with these large clouds for times in the order of 10 $20 \mathrm{~min}$. Therefore the predicted trend of the ratio of oxala- te:glyoxylate as a function of in-cloud time should provide a meaningful comparison to GoMACCS measurements.

[32] The general trend predicted for a typical cloud cycle is that the ratio of oxalate:glyoxylate decreases and then increases with increasing cloud-contact time (Figure 8). The trend and absolute values of the oxalate:glyoxylate ratio predicted were similar for the "clean" and "polluted" simulations. The range of values predicted agree with ambient GoMACCS measurements; thus the residence times of parcels in GoMACCS clouds are consistent with that needed for the observed chemical changes in the oxalate:glyoxylate ratio in cloud. The multistep nature of oxalic acid production leads to more efficient production in the upper portions of clouds; in addition, the upper portions of clouds usually exhibit higher liquid water content (LWC) values, which increases droplet $\mathrm{pH}$, a condition favorable for oxalic acid production from glyoxylate oxidation [Sorooshian et al., 2007].

[33] It should also be noted that some of the highest oxalate levels were observed during spirals performed in clear air with clouds nearby. For instance, after profiling a single growing cumulus cloud, the aircraft performed a spiral descent from $3400 \mathrm{~m}$ to $700 \mathrm{~m}$ between the profiled cloud and other deep cumuli. Three total PILS samples were collected, where each sample represents aerosol over a third of the height range during the descent; the oxalate concentration increased with increasing altitude $(0.23$, $\left.0.34,0.41 \mu \mathrm{g} / \mathrm{m}^{3}\right)$. This suggests that significant amounts of cloud-processed aerosol containing organic acids might exist outside the edges of these deep cumuli. Sources of cloud-processed aerosol around the edges of cumulus clouds include detrainment out of the sides of clouds and transport from the cloud top region by downdrafts.

\subsection{High Nitrate Episodes: Methacrylic Acid in Cloud Droplets and Suppressed Organic Acid Formation}

[34] During two flights, the TO probed cloud fields above agricultural areas west of Houston where elevated levels of particulate nitrate $\left(>0.6 \mu \mathrm{g} / \mathrm{m}^{3}\right.$; up to $40 \%$ of total PILS mass) were observed. The TO also probed cloud fields within this same vicinity during three other flights when there were lower nitrate levels. During the five flights, the TO flew within the same altitude range (1000-3000 m). The below-cloud aerosol during high-nitrate flights exhibited higher $\mathrm{NH}_{4}^{+}: \mathrm{SO}_{4}^{2-}$ molar ratios (usually $>2$ ) as opposed to low-nitrate flights, indicating that there was enough $\mathrm{NH}_{3}$ to neutralize the $\mathrm{SO}_{4}^{2-}$, thereby allowing $\mathrm{NO}_{3}^{-}$to form in the particle phase from gaseous nitric acid $\left(\mathrm{HNO}_{3}\right)$ condensation with available $\mathrm{NH}_{3}$.

[35] During the flight with the largest average nitrate levels, the frequency of detection of methacrylate was relatively high compared to other flights, and was the only flight in which methacrylate was detected in droplet residual particle samples. Glyoxylic acid was also measured in the droplet residual samples. These data are consistent with the multiphase mechanism proposed by Claeys et al. [2004]; they observed that the ambient concentrations of 2-methyltetrols and 2-methylglyceric acid, the latter of which is proposed to have methacrylic acid as an intermediate, were enhanced under high- $\mathrm{NO}_{\mathrm{x}}$ conditions and that they could be formed by acid-catalyzed oxidation with hydrogen peroxide. Owing to the high particulate nitrate levels, both in and 


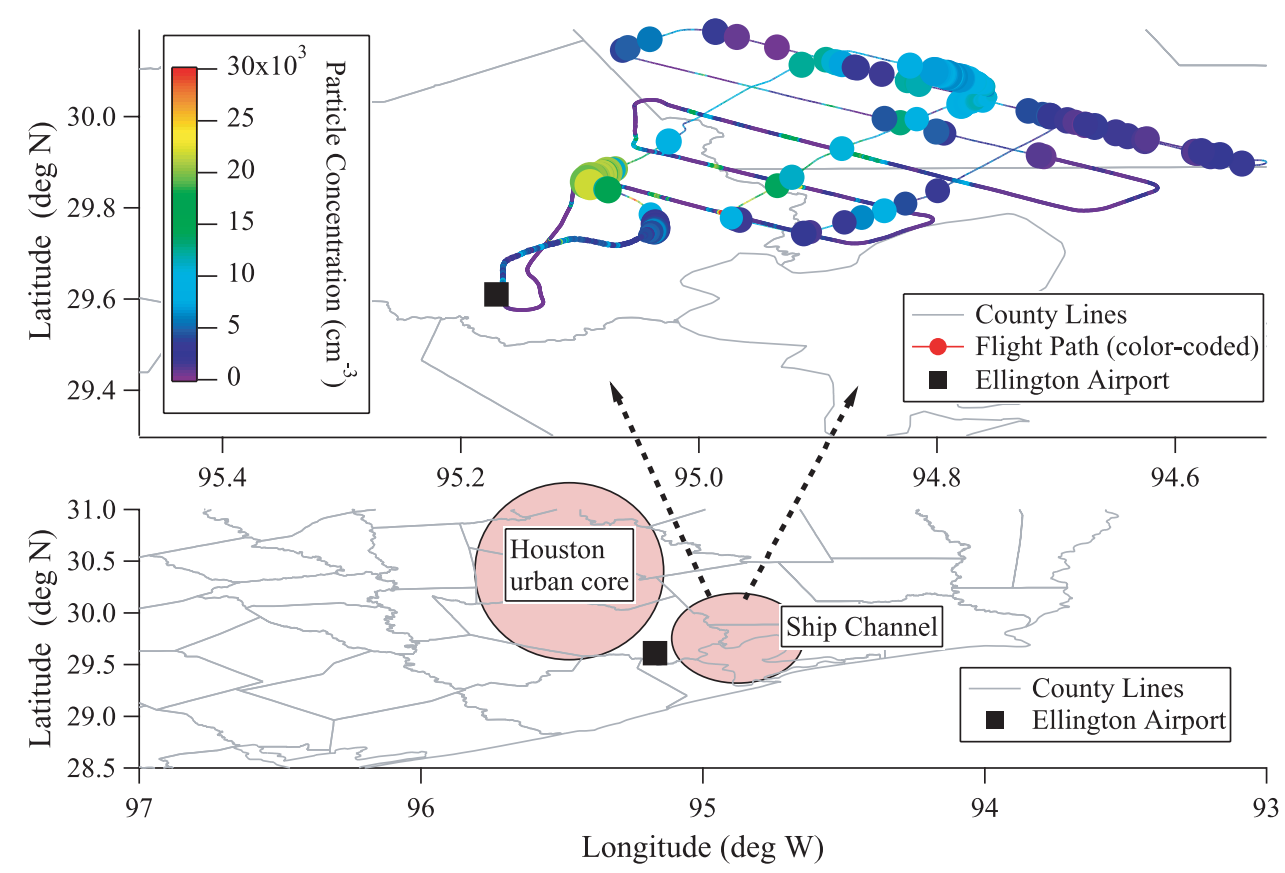

Figure 9. Flight tracks during a study aimed at analyzing the evolution of aerosol properties in three major plumes originating in the Houston Ship Channel. Markers are color-coded to represent fine particle $(<1 \mu \mathrm{m})$ number concentration, while marker sizes are proportional to PCASP $(0.1-2.5 \mu \mathrm{m})$ number concentration (range $=0-29,000 \mathrm{~cm}^{-3}$ ). There were southwesterly winds $\left(205-230^{\circ} ; 5-10 \mathrm{~m} / \mathrm{s}\right.$ ).

out of cloud, it is thought that high- $\mathrm{NO}_{\mathrm{x}}$ conditions existed and that the droplets were relatively acidic since the cloud LWC values were lower this flight compared to other flights. Methacrolein could have produced methacrylate in these acidic droplets, which could have been further oxidized to form 2-methylglyceric acid.

[36] Unlike the majority of the other cloud fields sampled during GoMACCS, the cloud fields experienced during the high-nitrate flights exhibited lower organic acid levels above cloud as compared to below [Sorooshian et al., 2007]. In the presence of high $\mathrm{HNO}_{3}$ levels and relatively lower LWC values, the droplets are more acidic (larger droplets would be more dilute), presumably suppressing organic acid formation. For example, the net production rate of oxalic acid in acidic droplets is suppressed because the rate constant of glyoxylic acid oxidation is an order of magnitude lower than that of glyoxylate [Ervens et al., 2003; Sorooshian et al., 2006a].

\section{Organic Acids Downwind of the Houston Ship Channel}

[37] One flight (flight 7; 28 August 2006) was devoted to studying the evolution of three different plumes from sources on the Houston Ship Channel (Figure 9), an area emitting a significant amount of VOCs, including aromatic hydrocarbons (http://www.esrl.noaa.gov/csd/2006/fieldops/ emission.html). Several crosswind transects were made to identify the largest plumes and then the plane flew 10 $15 \mathrm{~min}$ legs at $\sim 500 \mathrm{~m}$ going downwind inside three separate plumes. The fine particle number concentration was strongest at the source of plume $\mathrm{B}\left(37,000 \mathrm{~cm}^{-3}\right)$, followed by plume A $\left(14,000 \mathrm{~cm}^{-3}\right)$, and then plume $\mathrm{C}\left(8000 \mathrm{~cm}^{-3}\right)$. At a plume age of $1.5 \mathrm{~h}$ (plume ages calculated with distance from source and wind speed), plumes A and B were diluted to approximately $8000 \mathrm{~cm}^{-3}$, while plume $\mathrm{C}$ decreased to $1000 \mathrm{~cm}^{-3}$. On the other hand, the PCASP $(0.1-2.5 \mu \mathrm{m})$ number concentrations grew with plume age in plumes A, $\mathrm{B}$, and $\mathrm{C}$, reaching more than $20,000 \mathrm{~cm}^{-3}$ at plume ages of $1.5 \mathrm{~h}$; the majority of the particles in these plumes exceeded $1 \mu \mathrm{m}$ in diameter.

[38] The mass fractions of sulfate and ammonium together exceeded $80 \%$ in all three plumes from the source to a corresponding plume age of $1.5 \mathrm{~h}$. On average, the mass fraction of organic acids was greatest in plume A $(2.7 \%)$, followed by plumes B $(1 \%)$ and $\mathrm{C}(0.5 \%)$. Plume C exhibited the lowest volume $\left(2-2.5 \mu \mathrm{m}^{3} / \mathrm{cm}^{3}\right)$ and PILS mass $\left(2.5-3.5 \mu \mathrm{g} / \mathrm{m}^{3}\right)$ concentrations both at the source and downwind up to $40 \mathrm{~km}$, with little variation in the aerosol composition. Plumes A and B showed an increase in aerosol volume $\left(\sim 3\right.$ to $\left.4 \mu \mathrm{m}^{3} / \mathrm{cm}^{3}\right)$ and mass concentration $\left(\sim 4\right.$ to $\left.6 \mu \mathrm{g} / \mathrm{m}^{3}\right)$ from the source to a plume age of $1.5 \mathrm{~h}$. Sulfate continuously increased with downwind distance in both plume A and B. Between a plume age of 0.5 to $1.5 \mathrm{~h}$, the total organic acid concentration in plume A was stable at approximately $0.09 \mu \mathrm{g} / \mathrm{m}^{3}$, unlike plume B, where it grew from 0.03 to $0.12 \mu \mathrm{g} / \mathrm{m}^{3}$. Of the total organic acid mass, acetate and formate collectively accounted for $\sim 5 \%$ and oxalate contributed $\sim 55 \%$ upwind of the three plumes, while downwind, acetate and formate accounted for 29$77 \%$ and oxalate contributed $6-56 \%$. During the early stages of the plumes $(<0.5 \mathrm{~h})$, the organic acid mass fraction of benzoate reached up to $9 \%$ and $25 \%$ in plumes A and B, respectively. It is likely that the SOA formed by gasto-particle conversion from aromatic emissions initially contained species such as benzoic acid, that were subsequently oxidized to form lower molecular weight organic acids (that were less volatile and more polar), dominated by 
Table 2. Organic Acid Product Distribution for a Series of $m$-Xylene Laboratory Chamber Photo-oxidation Experiments ${ }^{\mathrm{a}}$

\begin{tabular}{|c|c|c|c|c|c|c|c|c|c|c|c|c|}
\hline & \multirow{2}{*}{$\begin{array}{c}\text { Initial } \\
\text { VOC:NO }{ }_{\mathrm{x}} \\
\text { Ratio }\end{array}$} & \multirow{2}{*}{$\begin{array}{c}\text { DMA-Derived } \\
\text { SOA Mass, } \\
\mu \mathrm{g} / \mathrm{m}^{3}\end{array}$} & \multirow{2}{*}{$\begin{array}{c}\text { Organic } \\
\text { Acid Mass } \\
\text { Fraction of } \\
\text { SOA }\end{array}$} & \multicolumn{9}{|c|}{$\begin{array}{l}\text { Percent Contribution to Total Organic Acid Mass in the PILS } \\
\text { Sample Representing Maximum Total Organic Acid Mass }\end{array}$} \\
\hline & & & & Ace/Glyc/Lac & For & Pyr & $\mathrm{C}_{2}$ & $\mathrm{C}_{3}$ & $\mathrm{C}_{4}$ & $\mathrm{C}_{5}$ & Gly & Mle \\
\hline vlene/low NO & 17.1 & 90 & 0.41 & 41 & 29 & 20 & 5 & 2 & 2 & 1 & Det & 0.6 \\
\hline $75 \mathrm{ppb} m$-xylene/low $\mathrm{NO}_{\mathrm{x}} /$ nonacid & 8.5 & 81 & 0.38 & 45 & 28 & 17 & 5 & 2 & 2 & 1 & 0.2 & 0.9 \\
\hline $75 \mathrm{ppb} m$-xylene/low $\mathrm{NO}_{\mathrm{x}} /$ acid seed & 2500.0 & 93 & 0.35 & 42 & 33 & 15 & 6 & 1 & 1 & 1 & Det & 0.0 \\
\hline ne/low NO $\mathrm{NO}_{x} /$ nucleation & 29.2 & 97 & 0.36 & 37 & 37 & 16 & 5 & 1 & 1 & 2 & Det & 1.0 \\
\hline $300 \mathrm{ppb} m$-xylene/high $\mathrm{NO}_{\mathrm{x}} /$ nonacid seed & 0.3 & 65 & 0.18 & 30 & 31 & 21 & 8 & 4 & 4 & 2 & 0.1 & 0.0 \\
\hline $300 \mathrm{ppb} m$-xylene/high $\mathrm{NO}_{\mathrm{x}} /$ acid seed & 0.3 & 81 & 0.26 & 22 & 33 & 28 & 8 & 3 & 3 & 1 & 0.2 & 1.0 \\
\hline $300 \mathrm{ppb} m$-xylene/high $\mathrm{NO}_{\mathrm{x}} /$ nucleation & 0.3 & 75 & 0.17 & 30 & 34 & 21 & 7 & 2 & 3 & 1 & 0.2 & 2.0 \\
\hline
\end{tabular}

${ }^{\mathrm{a}} \mathrm{C}_{2}-\mathrm{C}_{5}$, dicarboxylic acids; For, formate; Ace, acetate; Pyr, pyruvate; Gly, glyoxylate; Mle, maleate; Glyc, glycolate; Lac, lactate. Those labels with "Det" indicate that glyoxylate exceeded detection limits during the experiment, but not in the sample representing the maximum organic acid mass observed.

acetic and formic acids and followed by oxalic acid. Plume $\mathrm{C}$ was composed entirely of acetate among all of the organic acids. An average of all clear air Ship Channel samples during the campaign show that the most abundant organic acids in decreasing order of their organic acid mass fractions are as follows: oxalate $(37 \%)$, acetate $(36 \%)$, formate $(9 \%)$, benzoate $(9 \%)$, and pyruvate $(4 \%)$; these results differ from other areas sampled because benzoate was actually detected, and oxalate contributed the least to the organic acid mass in this area, while acetate, formate, and pyruvate contributed relatively more.

\section{Evaluation of Ambient Data Relative to Laboratory Chamber Experiments of $m$-Xylene Photo-oxidation}

[39] The GoMACCS observations prompt the question of the extent to which particulate products measured in the Houston atmosphere match those of aromatic oxidation in a laboratory chamber. Laboratory tests in the dual $28 \mathrm{~m}^{3}$ Teflon chambers at Caltech were performed to study the organic acid product distribution from the photo-oxidation of a model aromatic hydrocarbon, $m$-xylene. A detailed description of these experiments and SOA yield are addressed elsewhere [ $\mathrm{Ng}$ et al., 2007], but selected results are briefly discussed here in relation to the field measurements. The chambers are surrounded by banks of black lights that are turned on after the injection of seed aerosol and gas phase reactants to initiate photo-oxidation. Seed aerosol, produced by atomizing a solution of ammonium sulfate, was first introduced into the chambers in these experiments. Sulfuric acid was added to the atomizing solution when studying the effects of acidic seed aerosol. For nucleation experiments, no seed was added. Nitrous acid (HONO) was introduced as a source of $\mathrm{OH}$ and $\mathrm{NO}_{\mathrm{x}}$ for a series of high- $\mathrm{NO}_{\mathrm{x}}$ tests; extra $\mathrm{NO}$ was added to ensure a $\mathrm{NO}_{\mathrm{x}}$ level near $\sim 1 \mathrm{ppm}$. For the low- $\mathrm{NO}_{\mathrm{x}}$ experiments, $\mathrm{H}_{2} \mathrm{O}_{2}$ served as the $\mathrm{OH}$ source. The range of initial VOC: $\mathrm{NO}_{\mathrm{x}}$ ratios during the experiments, $0.3-2500$ (Table 2), encompasses values expected in the Houston atmosphere.

[40] For the experiments conducted with $m$-xylene and the different $\mathrm{NO}_{\mathrm{x}}$ and seed conditions, the SOA mass fraction of organic acids was between $17 \%$ and $41 \%$ (Table 2); SOA mass was determined by multiplying the DMA volume concentration by a calculated SOA density (as determined by comparing DMA size distribution to the AMS size distribution; error $= \pm 0.10 \mathrm{~g} / \mathrm{cm}^{3}$ ). Higher organic acid mass fractions were exhibited during the low- $\mathrm{NO}_{\mathrm{x}}$ experiments $(35-41 \%)$, as compared to high- $\mathrm{NO}_{\mathrm{x}}$ conditions $(17-26 \%)$; however, the high- $\mathrm{NO}_{\mathrm{x}}$ organic acid mass fractions are likely an underestimate due to observed nitrate contamination in the laboratory chambers $\left(5-10 \mu \mathrm{g} / \mathrm{m}^{3}\right)$, which increased the volume concentration. The organic acid product distribution was similar for all the experiments; acetate $(22-45 \%)$ and formate $(28-37 \%)$ were the dominant products, followed by pyruvate $(15-28 \%)$, oxalate $(5-8 \%)$, and a set of other acids (malonate, succinate, glutarate, glyoxylate, and maleate were each $\leq 4 \%$ ). As stated earlier, acetate, lactate, and glycolate coelute, so it is likely that the contribution of acetate reported is an overestimate, while glycolate and lactate could have been products.

[41] Figure 10 shows the time evolution of all organic acids during one photo-oxidation experiment $(75 \mathrm{ppb}$ $m$-xylene/low $\mathrm{NO}_{\mathrm{X}} /$ nonacidic ammonium sulfate seed aerosol). The first organic acid products formed are acetate/ glycolate/lactate, formate, pyruvate, and oxalate, in decreasing level of concentration. Less abundant products included malonate, succinate, glutarate, maleate, and glyoxylate. All species stabilize in concentration within approximately four hours with the exception of oxalate, malonate, succinate, and glutarate, which continue to grow until the end of the experiment. For the first two hours of irradiation, the oxalate:malonate mass ratio increases from 2 to 4 , and then decreases steadily to 1.7 by the end of the experiment ( $9 \mathrm{~h}$ of irradiation). The malonate:succinate and succinate:glutarate ratios do not show such a trend over the duration of the experiment. One possibility is that the in the first two hours, malonic acid was more efficiently being photo-oxidized to form oxalic acid, and then in the final hours, malonate was being formed more efficiently. It has been suggested that some of the dicarboxylic acids from the photo-oxidation of aromatic VOCs could be dimers of monocarboxylic acids [Fisseha et al., 2004], which is consistent with the first step of polymerization as reported by Kalberer et al. [2004]. This could explain why oxalate, malonate, succinate, and glutarate were still increasing in concentration until the end of the experiment. Pyruvic acid, which exhibited most of its growth in the first two hours after lights were turned on, may be a compound involved in polymerization processes [Kalberer et al., 2004].

[42] Fisseha et al. [2004] also reported higher particulate concentrations of monocarboxylic acids as compared to dicarboxylic acids in their study of the photo-oxidation of 1,3,5-trimethylbenzene in the presence of $300 \mathrm{ppb}$ propene 


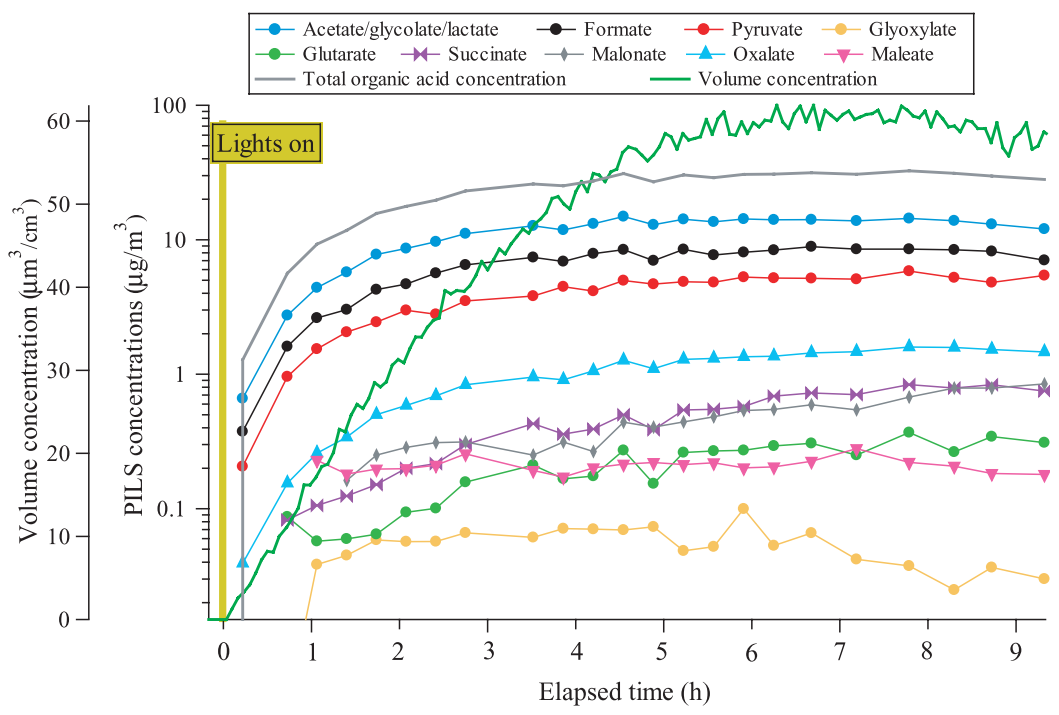

Figure 10. Organic acid product evolution from a photo-oxidation experiment with the following conditions: $75 \mathrm{ppb} m$-xylene/low $\mathrm{NO}_{\mathrm{x}} /$ nonacid ammonium sulfate seed aerosol. The organic acid mass fraction of the DMA-derived SOA mass was estimated to be approximately $39 \%$ at the time the sample with the maximum mass concentration was collected.

and $300 \mathrm{ppb} \mathrm{NO}_{\mathrm{x}}$; they reported that organic acids accounted for $20-45 \%$ of the aerosol mass formed, similar to results in this study. However, it should be noted that the aerosol sampling techniques used both in this study and that of Fisseha et al. [2004] rely on steam condensation, which may break down polymers to their monomers resulting in higher concentrations of organic acids such as acetic, formic, and pyruvic acids.

[43] These laboratory chamber results are consistent with acetate, formate, and pyruvate contributing more to the organic acid mass in the Ship Channel area compared to all other locations during GoMACCS. The higher contribution of oxalate in the Ship Channel area as compared to the laboratory chamber may be a result of a higher background level of oxalate in the area.

\section{Conclusions}

[44] Ambient measurements of water-soluble aerosol species were made on board the CIRPAS Twin Otter during the 2006 GoMACCS field campaign in southeastern Texas. Sulfate and ammonium dominated the water-soluble mass $\left(\mathrm{NH}_{4}^{+}+\mathrm{SO}_{4}^{2-}=84 \pm 14 \%\right)$. The average $\mathrm{NH}_{4}^{+}: \mathrm{SO}_{4}^{2-}$ molar ratio was $1.77 \pm 0.85$. The most acidic samples and highest sulfate loadings occurred downwind of the W. A. Parish Power Plant. The mass fraction of nitrate was usually less than $10 \%$, but elevated levels were observed west of Houston during two particular flights $\left(>0.6 \mu \mathrm{g} / \mathrm{m}^{3}\right.$; up to $40 \%$ of total PILS mass). The cloud fields in these areas were unique in that the droplet residual particles contained methacrylate, which is known to be formed under high- $\mathrm{NO}_{\mathrm{x}}$ conditions by the acid-catalyzed reaction of isoprene with hydrogen peroxide. Suppressed organic acid formation was also observed in the high nitrate-containing clouds since they were suspected of containing relatively acidic droplets.

[45] The average particulate water-soluble mass fraction of organic acids measured was $3.4 \pm 3.7 \%$; concentrations of organic acids increased with decreasing carbon number from $\mathrm{C}_{9}$ to $\mathrm{C}_{2}$. The organic acid mass fraction of oxalate, the most abundant organic acid measured, was greatest above cloud as a result of aqueous phase chemistry in cloud droplets followed by subsequent droplet evaporation above cloud tops. The observed distribution of organic acids as a function of altitude in cloud is consistent with the multistep nature of liquid phase oxalic acid production; predictions from a cloud parcel model agree with measurements that show that the oxalate:glyoxylate ratio decreases and then increases as a function of altitude in GoMACCS cumuli. Glyoxylate is likely formed rapidly with increasing altitude in the lower portion of clouds, which then allows it to efficiently produce oxalic acid in the upper portion.

[46] Oxalate, acetate, formate, benzoate, and pyruvate, in decreasing order, contributed the most to the organic acid mass in the Houston Ship Channel region, an area with significant VOC emissions. The chemical composition of the aerosol in this region was different from that in other areas around Houston in that benzoate was detected, oxalate contributed the least to the organic acid mass, while acetate, formate, and pyruvate contributed relatively more. In laboratory chamber experiments, the photo-oxidation of $m$-xylene, a model aromatic VOC, leads to a particulate organic acid product distribution consistent with Ship Channel observations. The chamber SOA mass fraction accounted for by organic acids ranged from $17-41 \%$, with higher values observed under low- $\mathrm{NO}_{\mathrm{x}}$ conditions, as compared to high- $\mathrm{NO}_{\mathrm{x}}$ conditions. Acetate/glycolate/lactate, formate, and pyruvate were the dominant products, accounting for $22-45 \%, 28-37 \%$, and $15-28 \%$ of the total organic acid mass, respectively.

[47] Atmospheric measurements of water-soluble aerosol species, especially organic acids, provide valuable data to constrain gas and particle/droplet phase chemistry. Organic acids identified in the Houston atmosphere give important clues as to the sources of the atmospheric organic aerosol in that region and in urban atmospheres in general. 
[48] Acknowledgment. This work was supported by NOAA grant NÁ06OAR4310082.

\section{References}

Angelino, S., D. T. Suess, and K. A. Prather (2001), Formation of aerosol particles from reactions of secondary and tertiary alkylamines: Characterization by aerosol time-of-flight mass spectrometry, Environ. Sci. Technol., $35,3130-3138$.

Appel, B. R., E. M. Hoffer, E. L. Kothny, S. M. Wall, M. Haik, and R. L. Knights (1979), Analysis of carbonaceous material in Southern-California atmospheric aerosols. 2., Environ. Sci. Technol., 13, 98-104.

Blando, J. D., and B. J. Turpin (2000), Secondary organic aerosol formation in cloud and fog droplets: A literature evaluation of plausibility, Atmos. Environ., 34, 1623-1632.

Calvert, J. G., R. Atkinson, K. H. Becker, R. M. Kamens, J. H. Seinfeld, T. J. Wallington, and G. Yarwood (2002), The Mechanisms of Atmospheric Oxidation of Aromatic Hydrocarbons, Oxford Univ. Press, New York.

Carlton, A. G., B. J. Turpin, H. J. Lim, K. E. Altieri, and S. Seitzinger (2006), Link between isoprene and secondary organic aerosol (SOA): Pyruvic acid oxidation yields low volatility organic acids in clouds, Geophys. Res. Lett., 33, L06822, doi:10.1029/2005GL025374.

Chebbi, A., and P. Carlier (1996), Carboxylic acids in the troposphere, occurrence, sources, and sinks: A review, Atmos. Environ., 30, $4233-$ 4249.

Claeys, M., W. Wang, A. C. Ion, I. Kourtchev, A. Gelencser, and W. Maenhaut (2004), Formation of secondary organic aerosols from isoprene and its gas-phase oxidation products through reaction with hydrogen peroxide, Atmos. Environ., 38, 4093-4098.

Crahan, K. K., D. Hegg, D. S. Covert, and H. Jonsson (2004), An exploration of aqueous oxalic acid production in the coastal marine atmosphere, Atmos. Environ., 38, 3757-3764.

Ervens, B., S. Gligorovski, and H. Herrmann (2003), Temperature-dependent rate constants for hydroxyl radical reactions with organic compounds in aqueous solutions, Phys. Chem. Chem. Phys., 5, 1811-1824.

Ervens, B., G. Feingold, G. J. Frost, and S. M. Kreidenweis (2004), A modeling study of aqueous production of dicarboxylic acids: 1. Chemical pathways and speciated organic mass production, J. Geophys. Res., 109, D15205, doi:10.1029/2003JD004387.

Faust, B. C. (1994), Photochemistry of clouds, fogs, and aerosols, Environ. Sci. Technol., 28, A217-A222.

Fisseha, R., J. Dommen, M. Sax, D. Paulsen, M. Kalberer, R. Maurer, F. Hofler, E. Weingartner, and U. Baltensperger (2004), Identification of organic aerosol and the acids in secondary corresponding gas phase from chamber experiments, Anal. Chem., 76, 6535-6540.

Forstner, H. J. L., R. C. Flagan, and J. H. Seinfeld (1997), Secondary organic aerosol from the photo-oxidation of aromatic hydrocarbons Molecular composition, Environ. Sci. Technol., 31, 1345-1358.

Gelencser, A., and Z. Varga (2005), Evaluation of the atmospheric significance of multiphase reactions in atmospheric secondary organic aerosol formation, Atmos. Chem. Phys., 5, 2823-2831.

Grassian, V. H. (2001), Heterogeneous uptake and reaction of nitrogen oxides and volatile organic compounds on the surface of atmospheric particles including oxides, carbonates, soot and mineral dust: Implications for the chemical balance of the troposphere, Int. Rev. Phys. Chem., 20, 467-548.

Grosjean, D. (1988), Aldehydes, carboxylic-acids and inorganic nitrate during NSMCS, Atmos. Environ., 22, 1637-1648.

Grosjean, D., and K. Fung (1984), Hydrocarbons and carbonyls in Los Angeles air, JAPCA J. Air Waste Manage. Assoc., 34, 537-543.

Grosjean, D., K. Vancauwenberghe, J. P. Schmid, P. E. Kelley, and J. N. Pitts (1978), Identification of C3-C10 aliphatic dicarboxylic-acids in airborne particulate matter, Environ. Sci. Technol., 12, 313-317.

Hamilton, J. F., P. J. Webb, A. C. Lewis, and M. M. Reviejo (2005), Quantifying small molecules in secondary organic aerosol formed during the photo-oxidation of toluene with hydroxyl radicals, Atmos. Environ., $39,7263-7275$.

Hatakeyama, S., T. Tanonaka, J. H. Weng, H. Bandow, H. Takagi, and H. Akimoto (1985), Ozone cyclohexene reaction in air-Quantitativeanalysis of particulate products and the reaction-mechanism, Environ. Sci. Technol., 19, 935-942.

Hatakeyama, S., M. Ohno, J. H. Weng, H. Takagi, and H. Akimoto (1987), Mechanism for the formation of gaseous and particulate products from ozone-cycloalkene reactions in air, Environ. Sci. Technol., 21, 52-57.

Huang, X. F., and J. Z. Yu (2007), Is vehicle exhaust a significant primary source of oxalic acid in ambient aerosols?, Geophys. Res. Lett., 34 , L02808, doi.10.1029/2006GL028457.

Huang, X. F., M. Hu, L. Y. He, and X. Y. Tang (2005), Chemical characterization of water-soluble organic acids in PM2.5 in Beijing, China, Atmos. Environ., 39, 2819-2827.

Huang, X. F., J. Z. Yu, L. Y. He, and Z. B. Yuan (2006), Water-soluble organic carbon and oxalate in aerosols at a coastal urban site in China:
Size distribution characteristics, sources, and formation mechanisms, J. Geophys. Res., 111, D22212, doi:10.1029/2006JD007408.

Iraci, L. T., B. M. Baker, G. S. Tyndall, and J. J. Orlando (1999), Measurements of the Henry's law coefficients of 2-methyl-3-buten-2-ol, methacrolein, and methylvinyl ketone, J. Atmos. Chem., 33, 321-330.

Jang, M. S., and R. M. Kamens (2001), Characterization of secondary aerosol from the photo-oxidation of toluene in the presence of $\mathrm{NO}_{x}$ and 1-propene, Environ. Sci. Technol., 35, 3626-3639.

Kalberer, M., J. Yu, D. R. Cocker, R. C. Flagan, and J. H. Seinfeld (2000), Aerosol formation in the cyclohexene-ozone system, Environ. Sci. Technol., 34, 4894-4901.

Kalberer, M., et al. (2004), Identification of polymers as major components of atmospheric organic aerosols, Science, 303, 1659-1662.

Kanakidou, M., et al. (2005), Organic aerosol and global climate modelling: A review, Atmos. Chem. Phys., 5, 1053-1123.

Kawamura, K., and R. B. Gagosian (1987), Implications of omega-oxocarboxylic acids in the remote marine atmosphere for photo-oxidation of unsaturated fatty-acids, Nature, 325, 330-332.

Kawamura, K., and K. Ikushima (1993), Seasonal-changes in the distribution of dicarboxylic-acids in the urban atmosphere, Environ. Sci. Technol., 27, 2227-2235.

Kawamura, K., and I. R. Kaplan (1987), Motor exhaust emissions as a primary source for dicarboxylic acids in Los Angeles ambient air, Environ. Sci. Technol., 21, 105-110.

Kawamura, K., and F. Sakaguchi (1999), Molecular distributions of water soluble dicarboxylic acids in marine aerosols over the Pacific Ocean including tropics, J. Geophys. Res., 104, 3501-3509.

Kawamura, K., L. L. Ng, and I. R. Kaplan (1985), Determination of organicacids $(\mathrm{C} 1-\mathrm{C} 10)$ in the atmosphere, motor exhausts, and engine oils, Environ. Sci. Technol., 19, 1082-1086.

Kawamura, K., H. Kasukabe, O. Yasui, and L. A. Barrie (1995), Production of dicarboxylic acids in the Arctic atmosphere at polar sunrise, Geophys. Res. Lett., 22, 1253-1256.

Kawamura, K., H. Kasukabe, and L. A. Barrie (1996a), Source and reaction pathways of dicarboxylic acids, ketoacids and dicarbonyls in Arctic aerosols: One year of observations, Atmos. Environ., 30, 1709-1722.

Kawamura, K., R. Semere, Y. Imai, Y. Fujii, and M. Hayashi (1996b), Water soluble dicarboxylic acids and related compounds in Antarctic aerosols, J. Geophys. Res., 101, 18,721-18,728.

Kawamura, K., Y. Imai, and L. A. Barrie (2005), Photochemical production and loss of organic acids in high Arctic aerosols during long-range transport and polar sunrise ozone depletion events, Atmos. Environ., 39, 599-614.

Kerminen, V. M., K. Teinila, R. Hillamo, and T. Makela (1999), Sizesegregated chemistry of particulate dicarboxylic acids in the Arctic atmosphere, Atmos. Environ., 33, 2089-2100.

Kerminen, V. M., C. Ojanen, T. Pakkanen, R. Hillamo, M. Aurela, and J. Merilainen (2000), Low-molecular-weight dicarboxylic acids in an urban and rural atmosphere, J. Aerosol Sci., 31, 349-362.

Khwaja, H. A. (1995), Atmospheric concentrations of carboxylic-acids and related-compounds at a semi-urban site, Atmos. Environ., 29, 127-139.

Kleindienst, T. E., T. S. Conver, C. D. McIver, and E. O. Edney (2004), Determination of secondary organic aerosol products from the photooxidation of toluene and their implications in ambient PM2.5, J. Atmos. Chem., 47, 79-100.

Kondo, Y., Y. Miyazaki, N. Takegawa, T. Miyakawa, R. J. Weber, J. L. Jimenez, Q. Zhang, and D. R. Worsnop (2007), Oxygenated and watersoluble organic aerosols in Tokyo, J. Geophys. Res., 112, D01203, doi:10.1029/2006JD007056.

Lim, H. J., A. G. Carlton, and B. J. Turpin (2005), Isoprene forms secondary organic aerosol through cloud processing: Model simulations, Environ. Sci. Technol., 39, 4441-4446.

Limbeck, A., and H. Puxbaum (1999), Organic acids in continental background aerosols, Atmos. Environ., 33, 1847-1852.

Ludwig, J., and O. Klemm (1988), Organic acids in different classes of atmospheric particulate material, Tellus, Ser. B, 40, 340-347.

Meylan, W. M., and P. H. Howard (1991), Bond contribution method for estimating Henry's law constants, Environ. Toxicol. Chem., 10, 1283-1293.

Mochida, M., N. N. Umemoto, K. Kawamura, and M. Uematsu (2003), Bimodal size distribution of C-2-C-4 dicarboxylic acids in the marine aerosols, Geophys. Res. Lett., 30(13), 1672, doi:10.1029/2003GL017451.

Murphy, S. M., A. Sorooshian, J. H. Kroll, N. L. Ng, P. Chhabra, C. Tong, J. D. Surratt, E. Knipping, R. C. Flagan, and J. H. Seinfeld (2007), Secondary aerosol formation from atmospheric reactions of aliphatic amines, Atmos. Chem. Phys. Disc., 7, 289-349.

Narukawa, M., K. Kawamura, N. Takeuchi, and T. Nakajima (1999), Distribution of dicarboxylic acids and carbon isotopic compositions in aerosols from 1997 Indonesian forest fires, Geophys. Res. Lett., 26, $3101-3104$

Neususs, C., M. Pelzing, A. Plewka, and H. Herrmann (2000), A new analytical approach for size-resolved speciation of organic compounds 
in atmospheric aerosol particles: Methods and first results, J. Geophys. Res., 105, 4513-4527.

Ng, N. L., J. H. Kroll, A. W. H. Chan, P. S. Chhabra, R. C. Flagan, and J. H. Seinfeld (2007), Secondary organic aerosol formation from m-xylene, toluene, and benzene, Atmos. Chem. Phys. Disc., 7, 4085-4126.

Norton, R. B., J. M. Roberts, and B. J. Huebert (1983), Tropospheric oxalate, Geophys. Res. Lett., 10, 517-520.

Peltier, R. E., A. P. Sullivan, R. J. Weber, A. G. Wollny, J. S. Holloway, C. A. Brock, J. A. de Gouw, and E. L. Atlas (2007), No evidence for acid-catalyzed secondary organic aerosol formation in power plant plumes over metropolitan Atlanta,Georgia, Geophys. Res. Lett., 34, L06801, doi:10.1029/2006GL028780.

Pereira, W. E., C. E. Rostad, H. E. Taylor, and J. M. Klein (1982), Characterization of organic contaminants in environmental samples associated with Mount St-Helens 1980 volcanic eruption, Environ. Sci. Technol., 16, $387-396$

Rogge, W. F., L. M. Hildemann, M. A. Mazurek, G. R. Cass, and B. R. T. Simoneit (1991), Sources of fine organic aerosol. 1. Charbroilers and meat cooking operations, Environ. Sci. Technol., 25, 1112-1125.

Rogge, W. F., M. A. Mazurek, L. M. Hildemann, G. R. Cass, and B. R. T. Simoneit (1993), Quantification of urban organic aerosols at a molecular level-Identification, abundance and seasonal variation, Atmos. Environ., 27, 1309-1330.

Rohrl, A., and G. Lammel (2001), Low molecular weight dicarboxylic acids and glyoxylic acid: Seasonal and air mass characteristics, Environ. Sci. Technol., 35, 95-101.

Russell, M., and D. T. Allen (2004), Seasonal and spatial trends in primary and secondary organic carbon concentrations in southeast Texas, Atmos. Environ., 38, 3225-3239.

Salam, A., H. Bauer, K. Kassin, S. M. Ullah, and H. Puxbaum (2003), Aerosol chemical characteristics of a mega-city in southeast Asia (Dhaka-Bangladesh), Atmos. Environ., 37, 2517-2528.

Satsumabayashi, H., H. Kurita, Y. Yokouchi, and H. Ueda (1989), Monoand di-carboxylic acids under long-range transport of air pollution in central Japan, Tellus, Ser. B, 41, 219-229.

Saxena, P., and L. M. Hildemann (1996), Water-soluble organics in atmospheric particles: A critical review of the literature and application of thermodynamics to identify candidate compounds, J. Atmos. Chem., $24,57-109$.

Sempere, R., and K. Kawamura (1994), Comparative distributions of dicarboxylic-acids and related polar compounds in snow rain and aerosols from urban atmosphere, Atmos. Environ., 28, 449-459.

Simoneit, B. R. T. (1986), Characterization of organic-constituents in aerosols in relation to their origin and transport-A review, Int. J. Environ. Anal. Chem., 3, 207-237.

Simoneit, B. R. T., and M. A. Mazurek (1982), Organic matter of the troposphere. 2. Natural background of biogenic lipid matter in aerosols over the rural western United States, Atmos. Environ., 16, 2139-2159.

Sorooshian, A., et al. (2006a), Oxalic acid in clear and cloudy atmospheres: Analysis of data from International Consortium for Atmospheric Research on Transport and Transformation 2004, J. Geophys. Res., 111, D23S45, doi:10.1029/2005JD006880.

Sorooshian, A., F. J. Brechtel, Y. L. Ma, R. J. Weber, A. Corless, R. C. Flagan, and J. H. Seinfeld (2006b), Modeling and characterization of a particle-into-liquid sampler (PILS), Aerosol Sci. Technol., 40, $396-409$.
Sorooshian, A., M.-L. Lu, F. J. Brechtel, H. Jonsson, G. Feingold, R. C. Flagan, and J. H. Seinfeld (2007), On the source of organic acid aerosol layers above clouds, Environ. Sci. Technol, doi:10.1021/es0630442, in press.

Souza, S. R., P. C. Vasconcellos, and L. R. F. Carvalho (1999), Low molecular weight carboxylic acids in an urban atmosphere: Winter measurements in Sao Paulo City, Brazil, Atmos. Environ., 33, 2563-2574.

Stephanou, E. G., and N. Stratigakis (1993), Oxocarboxylic and alpha,omegadicarboxylic acids-Photo-oxidation products of biogenic unsaturated fatty-acids present in urban aerosols, Environ. Sci. Technol., 27, 14031407.

Sullivan, A. P., R. E. Peltier, C. A. Brock, J. A. de Gouw, J. S. Holloway, C. Warneke, A. G. Wollny, and R. J. Weber (2006), Airborne measurements of carbonaceous aerosol soluble in water over northeastern United States: Method development and an investigation into water-soluble organic carbon sources, J. Geophys. Res., 111, D23S46, doi:10.1029/ 2006JD007072.

Talbot, R. W., K. M. Beecher, R. C. Harriss, and W. R. Cofer (1988), Atmospheric geochemistry of formic and acetic-acids at a mid-latitude temperate site, J. Geophys. Res., 93, 1638-1652.

Talbot, R. W., B. W. Mosher, B. G. Heikes, D. J. Jacob, J. W. Munger, B. C. Daube, W. C. Keene, J. R. Maben, and R. S. Artz (1995), Carboxylicacids in the rural continental atmosphere over the eastern United States during the Shenandoah Cloud and Photochemistry Experiment, J. Geophys Res., 100, 9335-9343.

Turekian, V. C., S. A. Macko, and W. C. Keene (2003), Concentrations, isotopic compositions, and sources of size-resolved, particulate organic carbon and oxalate in near-surface marine air at Bermuda during spring, J. Geophys. Res., 108(D5), 4157, doi:10.1029/2002JD002053.

Warneck, P. (2003), In-cloud chemistry opens pathway to the formation of oxalic acid in the marine atmosphere, Atmos. Environ., 37, 2423-2427.

Yamasoe, M. A., P. Artaxo, A. H. Miguel, and A. G. Allen (2000), Chemical composition of aerosol particles from direct emissions of vegetation fires in the Amazon Basin: Water-soluble species and trace elements, Atmos. Environ., 34, 1641-1653.

Yao, X. H., M. Fang, and C. K. Chan (2002), Size distributions and formation of dicarboxylic acids in atmospheric particles, Atmos. Environ., 36, 2099-2107

Yao, X. H., A. P. S. Lau, M. Fang, C. K. Chan, and M. Hu (2003), Size distributions and formation of ionic species in atmospheric particulate pollutants in Beijing, China: 2-dicarboxylic acids, Atmos. Environ., 37, $3001-3007$

Yao, X. H., M. Fang, C. K. Chan, K. F. Ho, and S. C. Lee (2004), Characterization of dicarboxylic acids in PM2.5 in Hong Kong, Atmos. Environ., 38, 963-970.

Yokouchi, Y., and Y. Ambe (1986), Characterization of polar organics in airborne particulate matter, Atmos. Environ., 20, 1727-1734.

Yu, J. Z., S. F. Huang, J. H. Xu, and M. Hu (2005), When aerosol sulfate goes up, so does oxalate: Implication for the formation mechanisms of oxalate, Environ. Sci. Technol., 39, 128-133.

A. W. H. Chan, R. C. Flagan, N. L. Ng, J. H. Seinfeld, and A Sorooshian, Department of Chemical Engineering, California Institute of Technology, Pasadena, CA 91125, USA. (seinfeld@caltech.edu)

G. Feingold, Chemical Sciences Division, Earth System Research Laboratory, NOAA, Boulder, CO 80305, USA 